
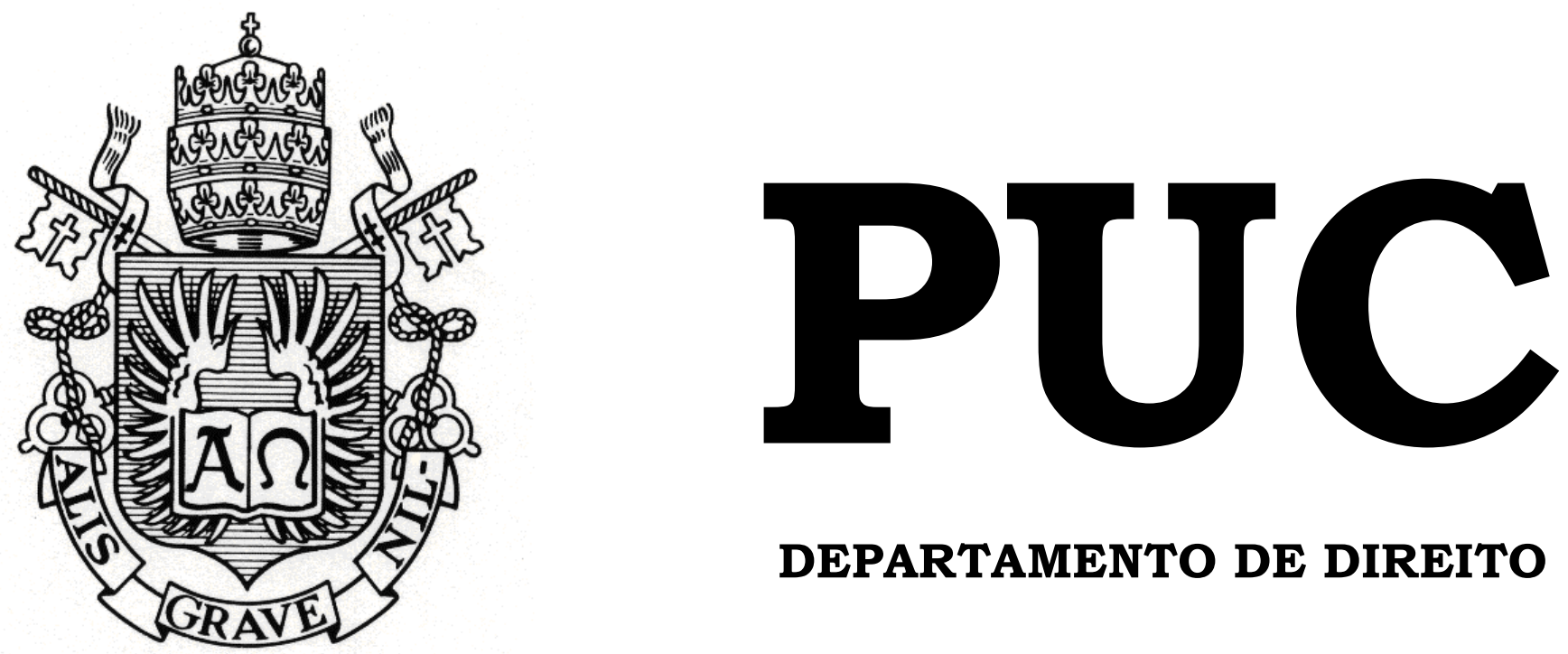

DEPARTAMENTO DE DIREITO

\title{
GESTÃO METROPOLITANA E MOBILIDADE URBANA: OS ASPECTOS JURÍDICOS DA IMPLANTAÇÃO DO BRT TRANSBRASIL NA REGIÃO METROPOLITANA DO RIO DE JANEIRO
}

por

ALINE PEIXOTO DOS SANTOS

ORIENTADOR(A): VIRGÍNIA TOTTI GUIMARÃES 2016.1

RUA MARQUÊS DE SÃO VICENTE, 225 - CEP 22453-900 


\title{
GESTÃO METROPOLITANA E MOBILIDADE URBANA: OS ASPECTOS JURÍdICOS DA IMPLANTAÇÃO DO BRT TRANSBRASIL NA REGIÃO METROPOLITANA DO RIO DE JANEIRO
}

\author{
por \\ ALINE PEIXOTO DOS SANTOS
}

Monografia

apresentada

ao

Departamento de Direito da Pontificia Universidade Católica do Rio de Janeiro (PUC-Rio) para a obtenção do Título de Bacharel em Direito.

Orientador(a): Virgínia Totti Guimarães

2016.1 


\section{DEDICATÓRIA}

Certa vez, quando estava esperando o início de uma das minhas aulas na faculdade, escutei uma das minhas colegas de classe analisando que não valia mais a pena ter um smartphone de determinada marca, pois, segundo ela, o bem que antes era símbolo de status, agora poderia ser comprado por qualquer "paraíba".

Esse trabalho é para nós "paraíbas" que somos atingidos diretamente pela falta de planejamento de nossas cidades, que perdemos horas e horas em um sistema de mobilidade arcaico e confuso feito apenas para determinada parcela da população.

É para aqueles que sentem o peso de estar em um lugar que originariamente não foi concebido para você e ter que aguentar que, em alguns momentos, o esforço pessoal apenas não é o suficiente.

No final o que importa é não desistir!

"Eu aumento o volume da música, coloco meus discos para tocar Debaixo das pedrinhas soa uma música rebelde

Não quero ver outra geração desistir Prefiro ser uma vírgula do que um ponto final" - Every Teardrop Is a Waterfall, Coldplay 


\section{AGRADECIMENTOS}

Primeiramente, a Deus por ter me sustentado, renovado as minhas forças, meu ânimo para chegar até aqui, ouvido minhas orações e ter me dado a oportunidade de estudar nesta universidade.

A minha mãe e meu pai pelo amor, carinho, por todos os conselhos e puxões de orelha, por ter enxugado minhas lágrimas e me dado ânimo, pelo esforço dedicado ao longo dos anos e o exemplo de persistência que me inspira.

A minha irmã pelo companheirismo e amor e por ter, junto com meus pais e amigos, aturado que falasse da monografia sem parar...

Aos meus avós, pois ainda que tenham ido há anos atrás, a memória do afeto e da determinação me orgulham e permanecem até hoje.

As minhas amigas "Biancas" que dividem comigo as risadas, as tristezas e os sonhos.

A minha amiga, irmã e sócia Beatriz com quem eu posso contar em todas as horas e que tem me aturado durantes os últimos cinco anos.

A Mariana pelo afeto e o jeito com as palavras.

A minha orientadora Virgínia por ter sido uma orientadora no verdadeiro sentido da palavra.

A todos vocês meu muito obrigada! 


\section{RESUMO}

A presente monografia tem por objetivo analisar os impactos da implantação do corredor BRT TransBrasil na região metropolitana do Rio de Janeiro, considerando a perspectiva constitucional da política urbana e o tratamento das regiões metropolitanas, em especial quanto à execução das funções públicas de interesse comum e à política nacional de mobilidade urbana. Além de ter como parâmetro os conceitos de direito a cidades sustentáveis, acessibilidade e gestão democrática.

Palavras-chave: região metropolitana, funções públicas de interesse comum, mobilidade urbana, direito à cidade, BRT TransBrasil. 


\section{SUMÁRIO}

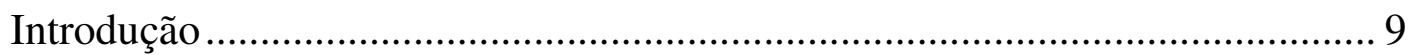

1) Regiões Metropolitanas no direito brasileiro ............................................. 12

1.1)A questão urbana no direito constitucional ........................................ 14

1.2) O tratamento constitucional das Regiões Metropolitanas .................... 18

1.2.1) Funções públicas de Interesse comum: o desafio das regiões

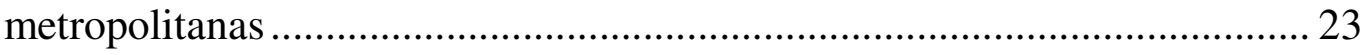

1.2.1) Questões relativas à implantação e funcionamento das Regiões

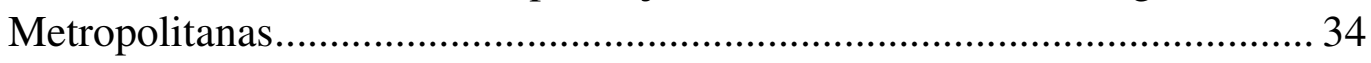

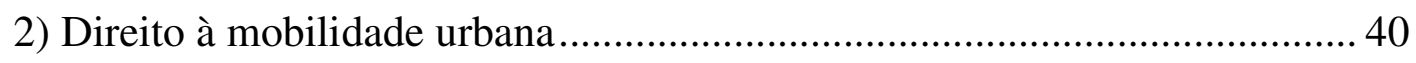

2.1) Direito à cidade, gestão democrática e mobilidade urbana .................. 42

2.2) Direito à mobilidade urbana na Constituição Federal de 1988 ............. 45

2.3) Planejamento e mobilidade urbana ....................................................... 49

3) Efeitos da implantação do corredor BRT TransBrasil na região metropolitana do Rio de Janeiro ....................................................... 55

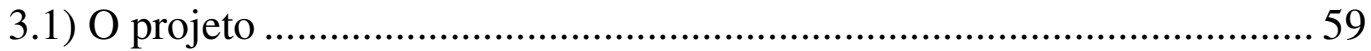

3.2) Interesse local ou metropolitano? Os aspectos jurídicos da implantação do BRT TransBrasil para a região metropolitana do Rio de Janeiro ............ 62

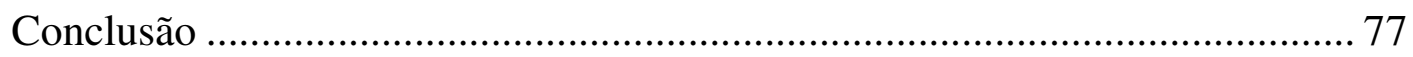

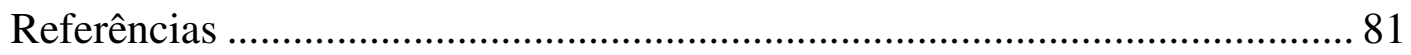




\section{LISTA DE ILUSTRAÇÕES}

Figura 1: região metropolitana do Rio de Janeiro .......................................56

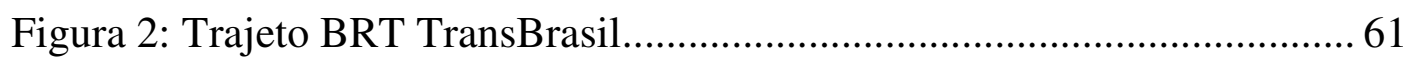

Figura 3: Configuração atual dos corredores BRTs ....................................... 62

Figura 4: Empregos na indústria na região metropolitana do Rio de Janeiro .. 64

Figura 5: Empregos no setor de serviços na região metropolitana do Rio de

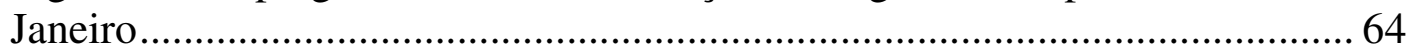

Figura 6: Empregos no setor de comércio na região metropolitana do Rio de

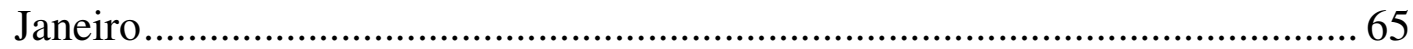

Figura 7: pessoas que trabalham na cidade do Rio de Janeiro ........................ 66

Figura 8: divisão de modais de transporte na região metropolitana do Rio de

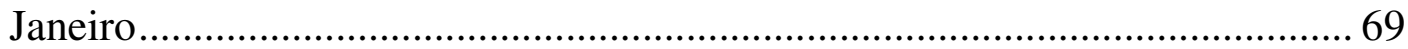

Figura 9: Novos BRTs na região metropolitana do Rio de Janeiro.................. 73 


\section{LISTA DE ABREVIAÇÕES E SIGLAS}

ADI

BRT

CRFB

EC

FPIC

IBEU

IPTU

IPVA

ISS

MNRU

PDMU

PDUI

PEC

PL

RMRJ

STF

VLT
Ação direta de inconstitucionalidade

Bus rapid transit

Constituição da República Federativa do Brasil

Emenda constitucional

Função pública de interesse comum

Índice de bem-estar urbano

Imposto predial e territorial urbano

Imposto sobre a propriedade de veículos automotores

Imposto sobre serviços

Movimento Nacional de Reforma Urbana

Plano Municipal de mobilidade urbana

Plano diretor urbano integrado

Proposta de emenda constitucional

Projeto de lei

Região Metropolitana do Rio de Janeiro

Supremo Tribunal Federal

Veículo leve sobre trilhos 


\section{Introdução}

A Constituição Federal de 1988 trouxe diversas inovações ao direito brasileiro, entre elas algumas demandas do Movimento Nacional de Reforma Urbana em uma tentativa tardia de tutelar a questão urbana brasileira. Dentre as novidades está a transformação dos municípios em ente federativo e a atribuição aos estados para instituir as regiões metropolitanas com vistas a execução das funções públicas de interesse comum.

Em relação a criação das regiões metropolitanas, o artigo 25 parágrafo $3^{o}$ é o único dispositivo encontrado no texto constitucional sobre metrópoles, dando margem à diversas interpretações, desde o conceito de funções públicas de interesse comum até quais são os entes responsáveis por sua execução.

Em um primeiro momento esta tarefa coube a doutrina e a jurisprudência, esta última com o recente e importante acórdão do Supremo Tribunal Federal sobre o tema, determinando a gestão compartilhada dos entes em relação aos assuntos metropolitanos. Sendo posteriormente tratada pelo Estatuto das Metrópoles ao estabelecer as diretrizes da gestão metropolitana dando especial atenção a execução das funções públicas de interesse comum.

Um dos maiores problemas enfrentados nestes espaços é operacionalizar a cooperação dos entes que compõe as regiões metropolitanas. A Constituição Federal ao passo que avança ao reconhecer o município como ente federativo e colocá-lo como personagem principal do planejamento urbano, não trouxe outras disposições a respeito de como essa autonomia seria colocada em escala metropolitana. 
No campo da mobilidade urbana, a promulgação da política nacional que estabeleceu as diretrizes do sistema de mobilidade nas cidades brasileiras, bem como reconheceu os direitos dos usuários de transporte, trouxe novos parâmetros para avaliar a eficiência dos sistemas de transporte urbano e novas obrigações dos estados e municípios em oferecer um meio de deslocamento seguro, eficiente e minimamente confortável.

A ideia é articular a gestão metropolitana com a mobilidade urbana, a fim de verificar como as políticas de transporte devem ser elaboradas e executadas dentro de uma metrópole, considerando seus efeitos nos entes que a compõe. Observando também que a mobilidade urbana está diretamente ligada a efetivação do direito à cidade, enquanto elemento importante para garantir o acesso aos bens e serviços urbanos, bem como ao mercado de trabalho.

Em uma região metropolitana como a do Rio de Janeiro, cujo processo de urbanização seguiu o tradicional modelo centro-periferia, com a concentração das oportunidades de trabalho, educação e lazer em um único local da metrópole e as pessoas de classes de renda mais baixas residindo em regiões cada vez mais distantes destes centros, a mobilidade também aparece como um indicador de segregação social, razão pela qual a desarticulação e inadequação do sistema de transporte afeta a metrópole como um todo.

Segundo o IBEU, o índice de bem-estar urbano que tem por objetivo medir as condições coletivas de vida dos habitantes das metrópoles, cerca de $71 \%$ da área da região metropolitana do Rio de Janeiro tem condições de mobilidade urbana ruim ou muito ruim $^{1}$, em contrapartida os melhores indicadores do setor estão concentrados na cidade do Rio de Janeiro.

\footnotetext{
${ }^{1}$ O IBEU é composto por cinco dimensões: mobilidade urbana; condições ambientais urbanas; condições habitacionais urbanas; atendimento de serviços coletivos urbanos; infraestrutura urbana. (Instituto Nacional de Ciência e Tecnologia. Índice de Bem-estar Urbano. Disponível em:< https://www.google.com.br/url?sa=t\&rct=j\&q=\&esrc=s\&source=web\&cd=1\&cad=rja\&uact=8\&ved=0 ahUKEwjm_a63sunMAhVFGZAKHYSJAcQQFggcMAA\&url=http\%3A\%2F\%2Fwww.observatorio dasmetropoles.net\%2Fdownload\%2Findice_bem_estar_urbano.pdf\&usg=AFQjCNHtw9nadrxOKVsP 9rH3DL0aC09Lhw> Acesso em: 20 de maio de 2015)
} 
Um dos projetos apresentados pela prefeitura da cidade do Rio de janeiro para melhorar as condições de mobilidade urbana tem sido a implantação de corredores Bus Rapid Transit (BRT) em seu território. Trata-se de um corredor exclusivo de ônibus articulados, cuja obra está sendo executada sobre a responsabilidade exclusiva do município do Rio de Janeiro, sendo considerado um projeto de interesse local. Neste trabalho o que se pretende é analisar os impactos de um dos corredores BRTs: o TransBrasil, para os habitantes da região metropolitana a partir dos conceitos de governança interfederativa, do direito à cidade e à mobilidade.

Com este objetivo, inicialmente será tratada a questão metropolitana, desde as alterações trazidas pela Constituição de 1988, passando pelas disposições do estatuto da cidade, da metrópole e da importante decisão do Supremo Tribunal Federal sobre a execução das funções públicas de interesse comum.

Já no segundo capítulo é vista a questão da mobilidade urbana, seu papel no direito constitucional, as diretrizes e instrumentos da política nacional de mobilidade urbana e as relações entre direito à cidade, direito à mobilidade e seu status de função pública de interesse comum quando inserida em uma região metropolitana.

Por fim, no capítulo três será analisado o projeto do corredor BRT TransBrasil, considerando sua importância para a região metropolitana do Rio de Janeiro, as competências relativas a execução de funções públicas de interesse comum e a mobilidade urbana, buscando entender se a obra é verdadeiramente de interesse local. 


\section{1) Regiões Metropolitanas no direito brasileiro}

A metropolização mostra-se como um dos resultados mais interessantes do processo de urbanização brasileiro. A rápida e intensa concentração de pessoas nos espaços em busca de melhores oportunidades no mercado de trabalho em virtude da industrialização, fez aparecer núcleos centrais nas grandes cidades, ganhando importância a nível local, regional e nacional.

Gradativamente esses núcleos foram se expandindo e incorporando as áreas periféricas ${ }^{2}$ causando novamente a "concentração enorme de pessoas, atividades econômicas e poder político em territórios muito pequenos"33 com uma forte interdependência econômica, social, política, cultural e geográfica, de tal forma que o crescimento dos municípios limítrofes é tão rápido que suas fronteiras se tornam quase indistinguíveis.

Tal fenômeno até então ignorado pelo ordenamento jurídico, vem a ser tutelado através da institucionalização das regiões metropolitanas nas quais os municípios componentes são "atropelados por um processo que tem lógica própria e que os une de maneira indissociável, criando problemas comuns que só podem ser resolvidos de maneira coletiva" 4.

O processo de institucionalização das regiões metropolitanas foi dividido em duas fases: durante o regime militar que criou as primeiras regiões metropolitanas do Brasil e a segunda e atual fase com a Constituição de 1988 e

\footnotetext{
2 GOUVEIA, Ronaldo Guimarães. A questão metropolitana no Brasil. p.91. Disponível em: https://www.google.com.br/url?sa=t\&rct=j\&q=\&esrc=s\&source=web\&cd=4\&cad=rja\&uact=8\&ved=0 ahUKEwjQh8L5s-

nMAhVIgZAKHTxjArEQFggsMAM\&url=http\%3A\%2F\%2Fbooks.google.com.br\%2Fbooks\%2Fabo ut\%2FA_quest\%25C3\%25A3o_metropolitana_no_Brasil.html\%3Fid\%3Df4jp09317uIC\&usg=AFQjC NFeg1yQettsDI-Byxs-U_TgEXhqRA\&bvm=bv.122448493,d.Y2I. Acesso em: 09 de maio de 2016. 3FERNANDES, Edésio. Gestão metropolitana. Caderno Escola Legislativo, Belo Horizonte, v.7, n. 12, p. 70, jan./jun.2004.

4 Idem, p.71.
} 
sua importantes mudanças. Ambos os momentos serão melhor analisados neste capítulo.

No último censo realizado pelo IBGE, em 2010 o país possuía 35 regiões metropolitanas, que englobavam 444 municípios e eram distribuídas em 22 unidades da federação, sendo a região sul a que abrigava o maior número de regiões metropolitanas ${ }^{5}$.

Em 2015, segundo levantamento do Observatório das Metrópoles $^{6}$ o número de regiões metropolitanas passou para 71, abarcando 1.209 municípios, distribuídas em 24 unidades da federação e a maior parte delas concentrada na região nordeste.

O crescimento das regiões metropolitanas já existentes e o surgimento de novas só aumentam a complexidade dos problemas apresentados por estes espaços urbanos, na medida que demandam uma maior utilização de estruturas arcaicas e já desgastadas, tal como o uso do solo, o sistema de mobilidade urbana entre outros aspectos que não foram adequados para um cenário metropolitano.

As reivindicações do Movimento Nacional de Reforma Urbana incorporados pela atual Constituição Federal e os instrumentos previstos pelas leis infraconstitucionais em decorrência das disposições constitucionais, propõe uma mudança da forma de conceber e gerir as questões metropolitanas. Porém qual o papel e viabilidade dos novos instrumentos? O que são regiões metropolitanas para a lei brasileira? Quais os desafios jurídicos que se apresentam com as mudanças trazidas?

\footnotetext{
5 IBGE. Sinopse do censo demográfico 2010. Rio de Janeiro, 2011. Disponível em: http://www.ibge.gov.br/home/estatistica/populacao/censo2010/default_sinopse.shtm. Acesso em: 06 de maio de 2016.

${ }^{6}$ Observatório das Metrópoles. Unidades Territoriais Urbanas no Brasil: Regiões Metropolitanas, Regiões Integradas de Desenvolvimento Econômico e Aglomerações Urbanas em 2015. Disponível em:http://www.observatoriodasmetropoles.net/index.php?option=com_k2\&view=item\&id=1157\%3Ar elat\%C3\%B3rio-unidades-territoriais-urbanas-no-brasil\&Itemid=169. Acesso em: 06 de maio de 2016.
} 
É o que o presente capítulo busca tentar entender. Inicialmente, será feito um apanhado das principais alterações da Constituição de 88 no que toca a questão urbana, depois a mudança específica quanto as regiões metropolitanas e o desafio de sua implantação e gestão.

\section{1) A questão urbana no direito constitucional}

A questão urbana somente era tratada a partir da perspectiva do direito de propriedade, uma ótica completamente individualista e absoluta, que, por óbvio, foi incapaz de atender aos crescentes obstáculos enfrentados com a construção e crescimento dos espaços urbanos.

Com o intuito de mudar essa perspectiva o Movimento Nacional de Reforma Urbana ganha força durante o período de redemocratização promovido em virtude da queda do regime militar, propondo uma nova concepção do urbano através da crítica das práticas econômicas que tornam a cidade uma mercadoria e a defesa da democratização dos processos decisórios responsáveis pela definição e gestão de políticas e programas urbanos ${ }^{7}$.

Conforme indica Edésio Fernandes, a demanda do MNRU e demais organizações da sociedade resultou na Emenda Popular de Reforma Urbana que buscava a constitucionalização da autonomia do governo municipal, gestão democrática das cidades, direito social de moradia, direito à regularização de assentamentos informais consolidados, função social da propriedade urbana e o combate à especulação imobiliária nas áreas urbanas .

\footnotetext{
7 NOVAES, Patrícia Ramos. Política urbana e gestão democrática: 10 anos de Estatuto da Cidade. Disponível em: http://www.observatoriodasmetropoles.net/index.php?option=com_k2\&view=item\&id=499\%3Apol\% C3\%ADtica-urbana-e-gest\%C3\%A3o-democr\%C3\%A1tica-10-anos-de-estatuto-dacidade \&Itemid=165\&lang=pt. Acesso em: 06 de maio de 2016. ${ }^{8}$ FERNANDES, Edésio. Politica Urbana Na Constituição Federal De 1988 E Além: Implementando A Agenda Da Reforma Urbana No Brasil. Disponível em: https://www12.senado.leg.br/publicacoes/estudos-legislativos/tipos-de-estupublicacoes/volume-ivconstituicao-de-1988-o-brasil-20-anos-depois.-estado-e-economia-em-vinte-amudancas/politica-
} 
A maior parte dos pleitos foram acolhidos pela Constituição Federal, salvo o direito social à moradia que só foi incorporado no ano 2000 com a edição da Emenda Constitucional n²6. Já quanto a regularização dos assentamentos informais consolidados e a repressão a especulação imobiliária Edésio Fernandes destaca que:

O direito à regularização de assentamentos informais consolidados foi promovido por meio da aprovação de novos instrumentos jurídicos que visavam a viabilizar os programas de regularização fundiária, no que diz respeito tanto aos assentamentos em terras privadas (usucapião especial urbano) quanto aos assentamentos em terras públicas (concessão de direito real de uso). A necessidade de combater a especulação imobiliária foi explicitamente reconhecida, e novos instrumentos jurídicos foram criados com esse propósito, a saber, parcelamento, utilização e edificação compulsórios, imposto predial e territorial progressivo no tempo e desapropriaçãosanção. ${ }^{9}$

No tocante a função social da propriedade também houve significativas mudanças, embora não possua um conceito definido no texto constitucional, a ela é dado o status de princípio (art.5 ${ }^{\circ}$ XXIII e art.170, III - CRFB) de forma que o proprietário tem seu direito conservado, mas sua propriedade deverá observar a função social. Sobre o tema José Afonso da Silva destaca que:

[...] o princípio da função social não autoriza a suprimir, por via legislativa, a instituição da propriedade privada. Contudo, parece-nos que pode fundamentar até mesmo a socialização de algum tipo de propriedade, onde precisamente isso se torne necessário à realização do princípio, que se põe acima do interesse individual. Por isso é que se conclui que o direito de propriedade não pode mais ser tido como um direito individual ${ }^{10}$.

urbana-agricola-e-fundiaria-politica-urbana-na-constituicao-federal-de-1988-e-aleimplementando-aagenda-da-reforma-urbana-no-brasil. Acesso em: 06 de maio de 2015.

${ }^{9}$ Idem. P. 05.

${ }^{10}$ SILVA, José Afonso da. Apud ASSIS, Carolina Tavares; GRANADO, Emerson de Morais. A função social da propriedade urbana. Revista Eletrônica de Iniciação Científica. Itajaí, Centro de Ciências Sociais e Jurídicas da UNIVALI. v. 4, n.1, p. 382- 393, $1^{\circ}$ Trimestre de 2013. Disponível em: www.univali.br/ricc - ISSN 2236-5044. Acesso em: 07 de maio de 2016. 
Já a ideia de autonomia municipal defendida pelo MNRU representava um grande avanço na política urbana, pois o ente mais próximo do espaço urbano teria os instrumentos necessários para o seu planejamento e em tese possibilitaria uma maior possibilidade de participação popular na gestão da cidade.

Apesar da reivindicação ter ganhado força na redemocratização, a conquista do município como participante da federação vem de um processo gradual, a cada Constituição o município ganhava uma nova atribuição ${ }^{11} \mathrm{e}$ independência, mas somente com a Carta de 88 que ele se torna ente federativo, possuindo autogoverno, auto-administração e auto-organização. Sendo atribuídas diversas competências no artigo 30, das quais destacamos: i) legislar sobre assuntos de interesse local; ii) suplementar a legislação federal e a estadual no que couber; iii) organizar e prestar, diretamente ou sob regime de concessão ou permissão, os serviços públicos de interesse local, incluído o de transporte coletivo, que tem caráter essencial; e IV) promover, no que couber, adequado ordenamento territorial, mediante planejamento e controle do uso, do parcelamento e da ocupação do solo urbano.

Como resultado de todo este processo foi criado, na Constituição, o capítulo da Política Urbana. Embora ainda inserido na parte da "Ordem Econômica", o capítulo composto pelos artigo 182 e 183 coloca o ente municipal como principal responsável pela elaboração e execução do planejamento urbano, devendo elaborar o plano diretor que constitui instrumento básico da política de desenvolvimento e de expansão urbana, sendo obrigatório para cidades com mais de vinte mil habitantes, é ele quem define as diretrizes para o crescimento e gestão municipal, além de ter a tarefa importantíssima de conceituar o que é função social da propriedade.

\footnotetext{
${ }^{11}$ SOUZA, Celina. "Federalismo, desenho constitucional e instituições federativas no Brasil pós1988." Revista de Sociologia e Política 24.24 (2005): 105-122.
} 
Não obstante a inovação do capítulo, suas normas necessitam de regulamentação infraconstitucional, o que só veio em 2001 com a promulgação da lei federal $n^{\circ} 10.257$ que criou o Estatuto da Cidade, responsável por regulamentar o capítulo da política urbana da Constituição Federal acima mencionados, fincar diretrizes gerais e criar novos instrumentos para a concretização do desenvolvimento urbano sempre observando o uso da propriedade urbana em prol do bem coletivo, da segurança e do bem-estar dos cidadãos, bem como do equilíbrio ambiental ${ }^{12}$.

Além disso, o Estatuto também traz uma das reivindicações do MNRU ao dispor que as cidades devem ser geridas democraticamente, ou seja, com a participação ativa da população e de associações nos processos decisórios, quer por meio de consultas e audiências públicas ou planos e projetos de lei de iniciativa popular entre outros.

Em relação aos instrumentos de desenvolvimento urbano o Estatuto prevê ao longo de seu texto: i) instrumentos em geral; ii) o parcelamento, edificação ou utilização compulsórios, IPTU progressivo no tempo, desapropriação com títulos da dívida pública; iii) o direito de superfície; iv) a outorga onerosa do direito de construir; v) a transferência do direito de construir; vi) as operações urbanas consorciadas; vii) o direito de preempção; viii) o consórcio imobiliário; ix) e a Zona Especial de Interesse Social (Zeis).

Além disso, a Lei $\mathrm{n}^{\circ}$ 10.257/2011 trata dos planos diretores municipais mencionados na Constituição, ao qual cabe o planejamento seguro e ordenado da cidade para que ela possa se desenvolver de forma saudável, respeitados os critérios previstos na legislação.

Ante o exposto podemos concordar com Eduardo Fontes Hotz ${ }^{13}$ ao sintetizar a inovação da CRFB de 88 ao: i) reconhecer a realidade urbana como

\footnotetext{
12 Lei $10.257 / 2001$, art. $1^{\circ}$ parágrafo único.

${ }^{13}$ Hotz. Eduardo Fontes. A Organização metropolitana pós Constituição de 1988. São Paulo em perspectiva. São Paulo, 2014. p.93.
} 
objeto de políticas governamentais, com a responsabilização do município pela política urbana, obedecidas as diretrizes gerais da União; ii) criar instrumentos para a defesa e manutenção da função social da propriedade e iii) estabelecer o Plano Diretor como pedra fundamental da política de desenvolvimento e expansão urbana.

Embora, a autonomia municipal tenha conferido aos entes um maior espaço para a gestão urbana, ela se transforma em um obstáculo de difícil superação quando colocada nas regiões metropolitanas, já que nestes lugares a gestão deve articulada como será visto no próximo item.

\section{2) O tratamento constitucional das Regiões Metropolitanas}

No âmbito do direito constitucional, a Constituição Imperial de 1824 foi a primeira a tratar da questão urbana. Nos artigos 167 e 169 atribui a uma câmara a gerência econômica e municipal das cidades e vilas existentes, além de determinar a criação de uma Lei complementar para disciplinar casos específicos ${ }^{14}$.

Na República Velha a Constituição de 1891 apenas adotou formulações genéricas, dando indícios de uma autonomia municipal ao atribuir a esses entes competência para resolveram questões atinentes aos seus interesses. ${ }^{15}$ Esta mesma carta em seus artigos 65, $\S 1^{\circ}$ e art. 48 permitia que os Estados celebrassem acordos entre si para a resolução de assuntos comuns, sem caráter político. Esta possibilidade aparece mais como um exemplo de reafirmação do

\footnotetext{
${ }^{14}$ Art. 167: Em todas as Cidades, e Villas ora existentes, e nas mais, que para o futuro se crearem haverá Camarás, às quase compete o Governo econômico, e municipal das mesmas Cidades, e Villas. Art. 169: O exercício de suas funções municipais, formação de suas Posturas policiais, aplicação de suas rendas, e todas as suas particulares, e úteis atribuições, serão decretadas por uma Lei regulamentar;

15 Art.68, CF/1891: Os Estados organizar-se-ão de forma que fique assegurada a autonomia dos Municípios em tudo quanto respeite ao seu peculiar interesse;
} 
federalismo inaugurado com aquela Constituição (na qual foi conferida autonomia aos estados), do que como uma tentativa para a cooperação e solução de questões urbanas existentes e futuras.

Os dispositivos previstos na carta acima mencionada foram repetidos pela Constituição de 1934, acrescida a possibilidade de celebração de acordos com a União (antes os acordos permaneciam no âmbito estadual) para o exercício em conjunto de seus serviços, sendo aos municípios atribuída "a organização dos serviços de sua competência"16.

O mesmo ocorreu com a Constituição de 1946, que prosseguia avançando com a autonomia municipal ao dispor que a estes entes compete a organização dos serviços públicos de caráter local ${ }^{17}$.

Curiosamente, são os textos proclamados durante regimes políticos ditatoriais que avançam ao editar normas mais específicas quanto a questão urbana no que se refere a regiões metropolitanas, justamente para obter um maior controle sobre a questão. No Estado Novo, o artigo 29 da Constituição previu a possibilidade de criação de agrupamentos municipais, com personalidade jurídica limitada a seus fins, cabendo aos Estados regularem as condições de tais agrupamentos.

Já na ditadura militar, a Constituição de 1967 e a Emenda Constitucional de 1969 se destacam ao falar de forma inédita sobre as regiões metropolitanas, e a partir da perspectiva centralizadora característica do regime político vigente a época, atribuiu a União a competência para instituir regiões metropolitanas, in verbis:

\footnotetext{
${ }^{16}$ Art 26 - Os Municípios serão organizados de forma a ser-lhes assegurada autonomia em tudo quanto respeite ao seu peculiar interesse, e, especialmente: c) à organização dos serviços públicos de caráter local;

${ }^{17}$ Carta de 1946, art.28, b;
} 
$\S 10$ - A União, mediante lei complementar, poderá estabelecer regiões metropolitanas, constituídas por Municípios que, independentemente de sua vinculação administrativa, integrem a mesma comunidade sócio-econômica, visando à realização de serviços de interesse comum. (art. 167§10 - CF/1967)

Art. 164. A União, mediante lei complementar, poderá para a realização de serviços comuns, estabelecer regiões metropolitanas, constituídas por municípios que, independentemente de sua vinculação administrativa, façam parte da mesma comunidade sócio-econômica (art.164 - EC/69)

Esta iniciativa se deu por entender que a importância daquelas áreas urbanas ultrapassava os interesses municipais, sendo responsabilidade da União zelar pela sua gestão, o lócus da produção havia se deslocado para os grandes centros urbanos, na medida em que as cidades passaram a ser vistas não só como espaço de vivência, mas também como importantíssimas unidades de produção. ${ }^{18}$

Neste passo, foram criadas através da Lei complementar $\mathrm{n}^{\circ} 14$ as regiões metropolitanas de Belém, Belo Horizonte, Curitiba, Fortaleza, Porto Alegre, Recife, Salvador e São Paulo e, posteriormente com a edição da Lei complementar 20/74 foi instituída a região metropolitana do Rio de Janeiro.

Em que pese a evolução constitucional no tratamento do tema das regiões metropolitanas, a mais significativa mudança vem com a Constituição de 1988 ao implantar uma política urbana incorporando as demandas do Movimento Nacional de Reforma Urbana dando um tratamento específico a metropolização.

Em apenas um artigo a Carta trata das questões metropolitanas ao atribuir a competência aos estados para instituir regiões metropolitanas e outros institutos urbanos, mediante Lei complementar estadual.

Art. 25. Os Estados organizam-se e regem-se pelas Constituições e leis que adotarem, observados os princípios desta Constituição.

$[\ldots]$

${ }^{18}$ GOUVEIA, Ronaldo Guimarães. Obra citada. P. 90. 
$\S 3^{\circ}$ Os Estados poderão, mediante lei complementar, instituir regiões metropolitanas, aglomerações urbanas e microrregiões, constituídas por agrupamentos de municípios limítrofes, para integrar a organização, o planejamento e a execução de funções públicas de interesse comum.

A atual Constituição transportou o artigo sobre a criação de regiões metropolitanas para o campo da "Organização do Estado" o que revela uma mudança na postura do Constituinte ao compreender que o urbano ultrapassa aspectos meramente econômicos, não podendo ser dissociada da realidade em que se apresenta, sendo, mormente, uma questão de predominância regional, na qual a proximidade do legislador possui um papel fundamental ${ }^{19}$. No entanto, vemos as inovações trazidas pelo diploma ultrapassam a mera questão de passagem da competência de nível federal para estadual.

O primeiro aspecto que precisa ser considerado é a inauguração de um novo modelo de federalismo no Brasil, o federalismo de cooperação. A primeira estrutura federalista implantada no Brasil vem com a Constituição de 1891 já estruturando um federalismo de cooperação, ou seja, a distribuição e articulação dos entes através de suas competências, este modelo de federalismo perdurou até o regime militar de 64 no qual foi visto o exercício do federalismo de integração.

Como vimos na redemocratização temos a elevação do município ao status de ente federativo ${ }^{20}$, bem como a passagem do federalismo de integração para o federalismo de cooperação. Antes tínhamos o exercício de atribuições com a preponderância da União como uma clara limitação ao exercício das competências de estados e municípios, agora a integração se transforma em

\footnotetext{
${ }^{19}$ Alaor Caffé destaca que, embora a disposição constitucional seja de natureza organizacional, ela não pode ser entendida como uma autorização para a criação de um ente político-administrativo entre o Estado e o município com poder de legislar sobre a matéria regional. (ALVES, Alaôr Caffé. Regiões Metropolitanas, Aglomerações Urbanas e Microrregiões: Novas Dimensões Constitucionais da Organização do Estado Brasileiro. Pg..05. Disponível em: < http://www.pge.sp.gov.br/centrodeestudos/revistaspge/revista/tes1.htm >. Acesso em: 6 de outubro de 2015)

${ }^{20}$ Art. $1^{\circ}$ A República Federativa do Brasil, formada pela união indissolúvel dos Estados e Municípios e do Distrito Federal, constitui-se em Estado Democrático de Direito e tem como fundamentos[...]
} 
cooperação, onde as atribuições de cada ente devem ser exercidas de forma articulada a fim de que todos os interesses envolvidos sejam atendidos ${ }^{21}$.

É sob o paradigma do federalismo de cooperação que as metrópoles deverão ser geridas, pois a criação de regiões metropolitanas pressupõe a existência de vários municípios, exigindo-se a cooperação e coordenação entre estes entes e o Estado para a gestão das funções públicas de interesse comum, uma vez que algumas atividades executadas dentro destes espaços possuem impactos fora do âmbito municipal.

Alaôr Caffé Alves sintetiza muito bem esta mudança de paradigma ao dizer que:

[...] na atual estrutura institucional básica brasileira, não temos uma distribuição de competências de modo estanque e compartimentado, onde a predominância do interesse impera como princípio maior. Segundo o princípio da predominância do interesse, em muitas ocasiões não se tem clareza de qual é o interesse predominante, gerando situações ambíguas e não raros conflitos de competência. Na verdade, entre nós, exatamente em razão daquele desenvolvimento altamente integrado que caracteriza a dinâmica sócio-econômica contemporânea, triunfa a concepção solidária das instâncias governamentais federativas, onde as competências comuns e concorrentes sobrelevam às exclusivas ${ }^{22}$.

Prosseguindo, o texto constitucional não conceitua regiões metropolitanas, microrregiões e aglomerações urbanas. Coube aos juristas e posteriormente ao Estatuto das Metrópoles esta função, na doutrina encontramos os requisitos constitucionais para os três institutos: i) criação por meio de lei complementar estadual; ii) tratar-se de um conjunto de municípios limítrofes; cuja finalidade é iii) organização, planejamento e execução de

\footnotetext{
${ }^{21}$ ALVES, Alaôr Caffé. Op. Cit. O2.

${ }^{22}$ Ibidem. p. 03.
} 
funções públicas de interesse comum. ${ }^{23}$ Já José Afonso da Silva define os institutos como:

Região Metropolitana constitui-se de um conjunto de Municípios cujas sedes se unem com certa continuidade urbana em torno de um Município-polo. Microrregiões formam-se de grupos de Municípios limítrofes com certa homogeneidade e problemas administrativos comuns, cujas sedes não sejam unidades por continuidade urbana. Aglomerados urbanos carece de conceituação, mas, de logo, se percebe que se trata de áreas urbanas, sem um polo de atração urbana, quer tais áreas sejam das cidades sedes dos Municípios, como na baixada santista (em São Paulo), ou não.

A Constituição tratou das regiões metropolitanas sinteticamente, sendo deixadas várias questões em aberto, cabendo aos municípios e estados responde-las. Exemplo disso é a definição de funções públicas de interesse comum, a competência para executá-las, como articular a recente autonomia do município com a governança metropolitana?

Embora a Constituição tenha atribuído ao Estado a tarefa de instituir as regiões metropolitanas através de Lei complementar, não foi autorizada a gestão isolada das metrópoles, sobrepondo-se o interesse do Estado sobre o dos demais entes que compõe as regiões metropolitanas.

\subsection{1) Funções públicas de Interesse comum: o desafio das regiões metropolitanas}

A caracterização de um espaço como uma metrópole vai além do fenômeno da conurbação, além da alteração geográfica do local e a confusão entre as linhas que dividem os municípios, é preciso existir uma verdadeira comunicação entre as cidades que as tornem interdependentes.

\footnotetext{
23 MORAES, Alexandre de. Apud. FILHO, Tarcísio Henriques. Regiões metropolitanas e autonomia dos municípios. RDA - revista de Direito Administrativo, Rio de Janeiro, v. 264, p. 135-159, set/dez. 2013.
} 
Neste sentido, certos serviços não estariam sujeitos mais apenas a um município já que a sua execução impactaria todas as outras cidades envolvidas, sendo necessária a articulação dos entes envolvidos.

Entretanto, essa cooperação tem na política e no direito seus dois maiores obstáculos. Na primeira é preciso ter em mente que em um único município há interesses políticos completamente divergentes, o que já dificulta o desenvolvimento dentro daquele ente quanto mais a articulação de diversos entes com seus próprios interesses partidários.

Já do ponto de vista jurídico as principais dificuldades são a conceituação de funções públicas de interesse comum e a competência para sua gestão que serão tratadas logo adiante.

Como se sabe a questão metropolitana foi uma das alterações promovidas pela Constituição atual, no entanto não foi apenas a competência para a instituição de regiões metropolitanas que mudou de ente, a própria função pública sofreu alterações.

Na Carta de 1967 e na Emenda Constitucional de 69 tínhamos os "serviços comuns de interesse metropolitano" hoje temos as funções públicas de interesse comum. A alteração vai além do campo gramatical ela também se torna mais abrangente, capaz de se adequar a figuras que vão além das regiões metropolitanas, como as aglomerações urbanas. Outrossim, a substituição pelo vocábulo "função" tem por escopo abarcar atividades que não se compreendem na noção de "serviço", tais como a ordenação e uso do solo urbano metropolitanos, entre outros.

Quanto ao vocábulo interesse podemos distingui-lo entre local e comum. O primeiro está positivado na Constituição de 88 no artigo 30, o qual determina que a competência para legislar sobre assuntos de interesse local é do município, bem como a organização e prestação de serviços públicos de interesse comum. 
Disso se depreende que havendo um conflito na execução de algum serviço envolvendo um interesse regional e o interesse local, a competência do município será predominante, mas a aferição do que pode ser considerado interesse local é casuística, ou seja, depende de uma análise do caso concreto.

A expressão "interesse local" trazida pela Constituição de 88 vem substituir o "interesse peculiar" contido nas Constituições anteriores ao falar sobre os municípios. Para parte da doutrina a modificação de palavras não significa uma diferença de tratamento, mas para Pontes de Miranda o “interesse comum” possui um papel significativo quando aliado a nova posição que o município ocupa na ordem constitucional atual. Enquanto a primeira expressão dependia do espaço não preenchido por leis federais e estaduais, a segunda não depende diretamente de tal condição ${ }^{24}$.

Diogo de Figueiredo Moreira Neto ${ }^{25}$ procurou identificar os aspectos que caracterizariam o interesse local através da conjugação das definiç̧ões de vários autores. Assim o interesse local dos municípios deve ser interno às cidades e vilas, que se pode isolar, territorialmente limitado ao município, sem repercussão externa ao município, próprio das relações de vizinhança, simultaneamente oposto a regional e nacional e dinâmico.

Já o interesse comum não respeita os critérios acima identificados, ao contrário ele não está adstrito ao território de apenas um município e repercute em todos os entes que estão a sua volta. Como veremos a frente autores como Diogo de Figueiredo, Luís Roberto Barroso, Hely Lopes Meireles entre outros defendem que tudo o que não é de interesse local e, portanto, de competência do município deve ser uma atribuição do estado.

\footnotetext{
${ }^{24}$ SOUZA, LEONARDO DA ROCHA DE. Interesse local versus peculiar interesse: análise da atuação dos municípios. rda - revista de Direito Administrativo, Rio de Janeiro, v. 261, p. 115-145, set./dez. 2012.

${ }^{25}$ MOREIRA NETO, Diogo de Figueiredo. Poder concedente para o abastecimento de agua. Revista de direito administrativo, Rio de janeiro:213, jul/set 1998.
} 
A partir da junção das expressões "funções públicas" e “interesse comum" chegamos a figura citada pelo constituinte. Para Eros Roberto Grau ${ }^{26}$ as funções públicas de interesse comum podem ser caraterizadas como aquelas "atividades e serviços urbanos, ou parte destes, que, pela natureza de sua disciplina, implantação ou operação, resultem em conexões e interferência recíprocas entre os diferentes municípios[...]".

Já de acordo com Alaôr Caffé Alves ${ }^{27}$ a função pública de interesse comum pode ser compreendida através do estudo dos conceitos que compõe seu enunciado: i) função pública: não implica apenas a execução de serviços públicos e de utilidade pública e respectivas concessões, mas também a normatização, o estabelecimento de políticas públicas; ii) interesse comum: que implica o vínculo simultâneo ou sucessivo, efetivo e material de ações ou atividades estáveis de uma multiplicidade determinada de pessoas políticoadministrativas, agrupadas mediante lei complementar, dentro de certo espaço territorial definido, para o exercício de funções públicas integradas de interesse de todos os envolvidos, ou seja, há uma interdependência operacional.

Este conceito não é uma definição estanque e ainda causa uma série de divergências quanto a competência para a realização das atividades qualificadas como funções públicas de interesse comum.

No entanto, neste assunto nada aparece como mais controvertido do que a gestão e competência para o desenvolvimento das funções públicas de interesse comum.

Isto porque vemos o embate entre a gestão isolada dos Estados instituidores de região metropolitana e o compartilhamento das funções comuns com os entes envolvidos.

\footnotetext{
${ }^{26}$ GRAU, Eros Roberto. Regiões Metropolitanas; regime jurídico. São Paulo: José Bushatsky, 1974. P.16.

${ }^{27}$ ALVES, Alaôr Caffé. Obra citada. Pg.15.
} 
$\mathrm{Na}$ esteira do primeiro entendimento está o raciocínio levantado por Diogo de Figueiredo Moreira $\mathrm{Neto}^{28}$, onde há uma clara contraposição entre o interesse local adstrito aos municípios e o interesse comum, segundo ele o interesse comum é aquele que transcende o municipal e passa a ser considerado estadual.

Aduz ainda que com a manutenção do instituto das regiões metropolitanas pela Constituição de 1988, as leis complementares federais que as regiam, foram recepcionadas como leis complementares estaduais, o que teria proporcionado ao Estado a atribuição de "manter a relação de serviços comuns, hoje funções públicas de interesse comum, ampliá-la ou reduzi-la como lhes parecer oportuno e conveniente" ${ }^{\prime 29}$.

$\mathrm{Na}$ mesma linha, Luís Roberto Barroso ${ }^{30}$ ressalta que os municípios são incapazes de prestarem sozinhos determinados serviços diante do seu alto custo e ineficiência, o que acarretaria prejuízos ao consumidor. Assim, caberia ao estado criar as regiões metropolitanas mediante lei complementar e através dela definir quais seriam as Funções públicas de interesse comum, que por consequência são de competência do estado.

Segundo os autores acima citados, a concentração das funções públicas de interesse comum nas mãos dos Estados é o que proporcionará a economicidade e eficiência aos serviços, assim a competência do estado não é apenas instituir a região metropolitana, mas sim geri-la conforme seu próprio entendimento proporcionando a eficiência desejada pelo constituinte.

Todavia, corroborar este entendimento é desconsiderar toda a evolução da questão urbana, principalmente quanto as regiões metropolitanas e

\footnotetext{
${ }^{28}$ MOREIRA NETO, Diogo de Figueiredo. Obra citada. p.08.

${ }^{29}$ MOREIRA NETO,Diogo de Figueiredo. Obra citada. pg.10.

${ }^{30}$ BARROSO, Luis Roberto. Saneamento básico: competências constitucionais da União, Estados e município. Revista Eletrônica de Direito administrativo econômico (REDAE). Pg.17. Salvador,
} 
inviabilizar uma solução adequada aos problemas enfrentados pelas metrópoles.

Conforme ressalta Alaôr Caffé Alves ${ }^{31}$ não estamos sob a égide do federalismo dual altamente centralizador, mas sim no federalismo de cooperação onde a articulação é o cerne para a divisão das competências. Ainda que seguíssemos a lógica compartimentada defendida por Diogo de Figueiredo Moreira Neto e Luís Roberto Barroso é preciso atentar que as regiões metropolitanas devem ter um tratamento diferenciado justificado pela própria essência sui generis do instituto.

Admitir as funções públicas de interesse comum como uma competência residual do Estado é inutilizar a figura das regiões metropolitanas e reconhecer que a Constituição Federal não foi capaz de atender as crescentes demandas urbanísticas, além disso se fosse simples competência residual não seria necessário a edição de Lei complementar, uma vez que tal atribuição está implícita na atual Constituição.

Uma interpretação sistemática, teleológica e sociológica permite inferir o oposto: o constituinte mudou o seu entendimento, a lógica centralizadora já não é mais adequada a diversos institutos muito menos a figura das regiões metropolitanas em que a gestão Interfederativa é a palavra de ordem. Até mesmo uma simples interpretação gramatical é capaz de verificar tal fato, já que vocábulo "comum" significa que "pertence a muitos ou a todos, que se faz conjuntamente" 32 .

A ideia trazida pelo constituinte é a do comum, ou seja, não é apenas o município, já que os serviços ultrapassam o interesse local, também não é o

Instituo Brasileiro de Direito público, $\mathrm{n}^{\circ} 11$, agosto/setembor/outubro, 2007. Disponível em: http://www.direitodoestado.com.br/redae.asp. Acesso em: 19 de outubro de 2015.

${ }^{31}$ ALVES, Alaôr Caffé. Obra citada. Pg..05.

${ }^{32}$ Dicionário online de português. Disponível em: <http://www.dicio.com.br/comum/>. Acesso em: 10 de out. 2015. 
Estado sozinho, a lógica consequencialista - de que pelo fato do estado ser competente para editar Lei complementar instituindo as regiões ele automaticamente é responsável por estas funções - não tem mais lugar em nosso ordenamento jurídico quando falamos de funções públicas de interesse comum $^{33}$.

O embate entre gestão centralizadora e gestão compartilhada ficou evidente no julgamento da Ação direta de inconstitucionalidade $\mathrm{n}^{\circ}$ 1842-9 ajuizada em face da lei complementar $n^{\circ}$. 87/1997, Lei $n^{\circ}$. 2.869/1997 e Decreto $n^{\circ}$. 24.631/1998, todos do Estado do Rio de Janeiro, que instituíram a região metropolitana do Rio de Janeiro e a microrregião dos Lagos definindo as funções públicas de interesse comum, atribuindo a titularidade do poder concedente para prestação dos serviços de saneamento básico metropolitano ao Estado do Rio de Janeiro.

Os autores da ação a propuseram por entenderem que a concessão do serviço de saneamento básico exclusivamente ao Estado do Rio de Janeiro frustra o propósito de cooperação entre municípios e Estado componente da região metropolitana, já que o referido serviço é uma função pública de interesse comum e, portanto, deveria ser exercida conjuntamente pelos entes envolvidos.

Assim, violaria os princípios constitucionais do equilíbrio federativo, da autonomia municipal, da não-intervenção dos Estados em seus Municípios, das competências municipais e comuns da União, do Estado e dos Municípios ${ }^{34}$.

Já os autores da norma impugnada, valeram-se dos mesmos argumentos já explicitados por Diogo de Figueiredo Moreira Neto e Luís Roberto Barroso

\footnotetext{
${ }^{33}$ Diogo de Figueiredo ressalta que " A lei complementar estadual que cria a região metropolitana, as aglomerações urbanas ou as microrregiões poderá (e, a rigor, deverá) especificar que serviços são considerados de interesse comum e, portanto, de titularidade do Estado, sendo-lhe legítimo fazê-lo nos termos do art. 25, $\S 3^{\circ}$, da Constituição". (MOREIRA NETO, Diogo de Figueiredo. Obra citada. p.11).

${ }^{34}$ Ação Direta de Inconstitucionalidade no $1842-R J, p .11$.
} 
ao defender a constitucionalidade dos dispositivos afirmando que "os serviços públicos que dependam de bens do Estado ou possam produzir consequências que ultrapassem os limites territoriais do Município deixam de ser da competência exclusiva deste" ${ }^{35}$, proporcionando eficiência e economicidade na prestação destes serviços.

Da leitura da ação fica evidente que a problemática dos dispositivos legais impugnados reside na violação ou não da autonomia dos municípios metropolitanos com a centralização do serviço de saneamento básico nas mãos de apenas um ente.

Segundo o artigo $5^{\circ}$, parágrafo único da Lei Complementar no 87/1997 o estado poderá conceder ou permitir serviços para fins de unificação e execução dos serviços comuns, sem a necessidade de deliberação dos munícipios participantes, ou seja, a autonomia dos entes envolvidos é reduzida a nada já que não possuem poder decisório.

Para solucionar a questão, os julgadores novamente se voltaram ao conceito de autonomia dos entes e a sua relação com a gestão metropolitana.

De acordo com o então ministro Joaquim Barbosa ${ }^{36}$ :

É essencial ter em mente que a autonomia municipal não possui apenas aspecto negativo, por tornar o município imune à interferência de outros entes federados respeitados, obviamente, os limites traçados pela Constituição federal. A autonomia municipal também possui nítido caráter positivo, por também se exercer quando órgãos colegiados metropolitanos permitem que o município seja ouvido e efetivamente decida sobre os interesses comuns da região (g.n.)

E prossegue afirmando que:

i) a restrição à autonomia dos municípios metropolitanos dá-se desde a configuração normativa constitucional, e não a partir da criação individual de cada região metropolitana, e (ii) a autonomia municipal realiza-se quando o município, num

\footnotetext{
35 Ibidem. P.12.

${ }^{36}$ Ação Direta de Inconstitucionalidade n ${ }^{\circ}$ 1842-RJ, p. 44.
} 
contexto metropolitano, tem preservada a capacidade de decidir efetivamente sobre os destinos da região.

A participação efetiva do município na região metropolitana se dá com a sua contribuição no processo decisório dos assuntos referentes ao espaço no qual está incluído e as funções públicas de interesse comum discutidas - neste caso o saneamento básico - precisam ser trabalhadas coletivamente, tal como preconiza o federalismo de integração.

Esta foi a posição adotada pelo então ministro Joaquim Barbosa ao votar a favor da inconstitucionalidade dos dispositivos impugnados na ação, ressaltando que ${ }^{37}$ :

[...] o exercício das funções públicas de interesse comum passa para a nova entidade público-territorial administrativa, de caráter intergovernamental, que nasce em consequência da criação da região metropolitana. Em contrapartida, o exercício das funções normativas, diretivas e administrativas do novo ente deve ser compartilhado com paridade entre o estado e os municípios envolvidos.

Da mesma forma entendeu o então ministro presidente do STF, Nelson Jobim $^{38}$ ao destacar que:

A região metropolitana é simplesmente um agrupamento relevante de municípios com o fim de executar funções públicas que, pela natureza dessas funções, exigem a cooperação entre esses municípios.

Esse agrupamento, por imposição constitucional, somente pode ser criado por lei complementar estadual.

Isso, entretanto, não significa que caiba ao estado as funções executivas de concretização dos chamados interesses metropolitanos.

O município continua a ser o titular das funções executadas pela região, muito embora seja, por imposição de lei estadual, uma titularidade que somente pode ser exercida em acordo ou em consenso com os demais municípios.

\footnotetext{
37 Ação Direta de Inconstitucionalidade no 1842-RJ, p. 46.

${ }^{38}$ Ibidem, p.77
} 
Em sentido contrário votou o ministro relator Maurício Correa, opinando pela manutenção do estado como prestador dos serviços de saneamento básico, uma vez que a ação unificada tenderia a promover um serviço eficiente e econômico, além de não estar em desacordo com o constituinte.

A ação foi julgada parcialmente procedente para declarar a inconstitucionalidade dos artigos $5^{\circ}$, I; e do $\S 2^{\circ}$ do art. $4^{\circ}$; do parágrafo único do art. $5^{\circ}$; dos incisos I, II, IV e V do art. $6^{\circ}$; do art. $7^{\circ}$; do art. 10 ; e do $\S 2^{\circ}$ do art. 11 da Lei Complementar n. 87/1997 do Estado do Rio de Janeiro, bem como dos arts. 11 a 21 da Lei n. 2.869/1997.

Importante destacar que a decisão ressaltou que a gestão dos serviços de saneamento básico poderia ser feita mediante convênios de cooperação ou consórcios públicos e que a participação dos entes envolvidos não precisaria ser paritária, mas apenas suficiente para evitar a concentração de poder em um dos entes envolvidos.

Em especial, quanto ao tema da transferência de competência para o Estado vale transcrever o seguinte trecho do acórdão ${ }^{39}$ :

O estabelecimento de região metropolitana não significa simples transferência de competências para o estado.

$[\ldots]$

O parâmetro para aferição da constitucionalidade reside no respeito à divisão de responsabilidades entre municípios e estado. É necessário evitar que o poder decisório e o poder concedente se concentrem nas mãos de um único ente para preservação do autogoverno e da autoadministração dos municípios.

A decisão da Corte pacificou de certa forma a discussão envolvendo a competência sobre as funções públicas de interesse comum, devendo ocorrer a gestão conjunta dessas funções, a partir de um processo decisório com a participação de todos os entes envolvidos, não necessariamente igualitária, mas 
sendo vedado que um ente decida isoladamente os assuntos relacionados a região metropolitana.

Assim, o acórdão determinou que o Estado do Rio de Janeiro crie novos mecanismos para o desenvolvimento do sistema de saneamento básico na metrópole do Rio de Janeiro que esteja de acordo com a Constituição.

Em obediência a decisão proferida, recentemente foi apresentado o projeto de Lei Complementar 10/2015 na Assembleia Legislativa do Rio de Janeiro que em seu texto propõe mudanças relacionadas a gestão de serviços metropolitanos, tais como a criação de uma autarquia para assuntos relacionados aos interesses metropolitanos com a participação de todos os municípios que compõe a região metropolitana do Rio.

A decisão do Supremo tribunal Federal na Ação Direta de Inconstitucionalidade $\mathrm{n}^{\mathrm{o}} 1.842$ - RJ também traçou um norte que foi posteriormente adotado pela lei $n^{\circ} 13.089 / 2015$ ao estabelecer uma estrutura de governança interfederativa, a fim de que nem o Estado nem os municípios tomem decisões isoladamente; a capacidade decisória de todos os entes deve ser preservada.

Esse modelo de gestão pressupõe o compartilhamento de responsabilidades e ações entre entes da Federação em termos de organização, planejamento e execução de funções públicas de interesse $\operatorname{comum}^{40}$ e deve respeitar os princípios da gestão democrática da cidade, prevalência do interesse comum sobre o local, da autonomia dos entes da Federação, do desenvolvimento sustentável, a observância das peculiaridades locais e regionais e o compartilhamento de responsabilidades.

\footnotetext{
${ }^{39}$ Ação Direta de Inconstitucionalidade n ${ }^{\circ} 1842-R J$, p. 3

${ }^{40}$ BRASIL. Lei ${ }^{\circ}$ 13.089, de 12 de Janeiro de 2015. Institui o Estatuto da Metrópole, altera a Lei no 10.257, de 10 de julho de 2001, e dá outras providências. Disponível em: <http://www.planalto.gov.br>. Acesso em: 30 jan. 2015.
} 
Com a nova lei a governança interfederativa não fica apenas papel e cargo das leis estaduais e municipais. $\mathrm{O}$ artigo $8^{\circ}$ da Lei $\mathrm{n}^{\circ} 13.089 / 2015$ estabelece a estrutura a ser observada: (i) instância executiva composta pelos representantes do Poder Executivo dos entes federativos integrantes das unidades territoriais urbanas; (ii) instância colegiada deliberativa com representação da sociedade civil; (iii) organização pública com funções técnico-consultivas; e (iv) sistema integrado de alocação de recursos e de prestação de contas.

Ato contínuo, as funções públicas de interesse comum também ganharam espaço no texto legal, inclusive com a sua conceituação no artigo $2^{\circ}$, inciso II, qual seja: "política pública ou ação nela inserida cuja realização por parte de um Município, isoladamente, seja inviável ou cause impacto em Municípios limítrofes". O que demonstra a importância destas funções para a metrópole a preocupação com um modelo de região metropolitana que seja capaz de atender as demandas urbanas.

Em termos práticos podem ser entendidas como funções públicas de interesse comum o saneamento básico, uso do solo e transporte entre outras.

\subsection{1) Questões relativas à implantação e funcionamento das Regiões Metropolitanas}

Inicialmente é preciso lembrar que as primeiras regiões metropolitanas foram criadas pela lei complementar federal $n^{\circ} 14$ impunham clara imposição da participação dos municípios nas metrópoles, a fim de que fossem executados os "serviços comuns de interesse metropolitano". Ou seja, as regiões metropolitanas eram instituídas pela União e as cidades envolvidas não poderiam levantar qualquer óbice a respeito de sua participação - um traço característico do regime ditatorial vigente a época. 
Com a redemocratização e a elevação do município a ente federativo e, portanto, dotado de autonomia, a compulsoriedade da participação deste ente torna-se algo a ser indagado.

Diante de tal incerteza jurídica algumas Constituições estaduais, em especial as cartas do Estado do Rio de Janeiro e do Espírito Santo ${ }^{41}$ trouxeram $^{2}$ em seu texto disposições sobre o assunto. Vejamos o que diz a Constituição do Estado do Rio de Janeiro em seu artigo 357:

A criação, a incorporação, a fusão e o desmembramento de municípios far-se-ão por Lei Estadual, dentro do período determinado por Lei Complementar Federal, e dependerão de consulta prévia, mediante plebiscito, às populações dos municípios envolvidos após a divulgação dos Estudos de Viabilidade Municipal, apresentados e publicados na forma da Lei.

Contudo, uma interpretação teleológica do artigo 25 parágrafo $3^{\circ}$ nos permite inferir que a simples faculdade da instituição de um convênio voluntário entre os entes federados localizados no espaço caracterizado como região metropolitana seria absolutamente incapaz de solucionar as crescentes demandas deste espaço urbano, principalmente quanto ao desempenho das funções de interesse comum.

Tal indagação foi levada até o Supremo Tribunal Federal com a Ação Direta de Inconstitucionalidade $\mathrm{n}^{\circ}$ 1.841-9 que declarou o artigo 357 da Constituição Estadual do Rio de Janeiro incompatível com a ordem constitucional estabelecida.

Em seu voto o relator, o então ministro Carlos Veloso ressaltou que a Constituição Federal em seu artigo 25 parágrafo $3^{\circ}$ trouxe como requisito único para a instituição de regiões metropolitanas, aglomerações urbanas e

\footnotetext{
${ }^{41}$ Art. 216. O território estadual poderá ser dividido mediante lei complementar, total ou parcialmente, em unidades regionais, tais como regiões metropolitanas, aglomerações urbanas e microrregiões constituídas por agrupamentos de Municípios limítrofes, para integrar a organização, o planejamento e a execução de funções públicas de interesses comuns, nos termos do art. 25, §3o, da Constituição Federal. §1o. A criação de regiões metropolitanas e aglomerações urbanas dependerá de consulta prévia, mediante plebiscito, às populações diretamente interessadas.
} 
microrregiões a edição complementar de competência estadual. Assim, ao impor mais uma exigência para a incorporação do município em uma região metropolitana, o artigo 357 da Constituição do Estado do Rio de Janeiro padecia de inconstitucionalidade material ${ }^{42}$.

A faculdade do ente de concordar com a sua inclusão em uma região metropolitana frustra o próprio espírito da Constituição Federal de facilitar a cooperação dos entes a fim de desenvolver com eficiência os serviços públicos comuns.

A autonomia municipal prevalece nas questões de ordem local, no entanto não se pode mostrar como um obstáculo ou conceito rígido e absoluto quando se depara com funções que transbordam os limites do município.

Assim, caso este ente esteja inserido em uma região metropolitana não há que se falar na predominância de sua autonomia diante de certas funções, já que, quando exercidas, os impactos estão além dos contornos municipais. Aliás, tal autonomia não é capaz de gerir isoladamente certas questões, nem seria justo que o exercício de uma atividade por um município afete diretamente outro ente sem que haja uma decisão comum, capaz de gerenciar os efeitos das políticas exercidas nestes lugares.

Frise-se que a participação compulsória do município na composição da região metropolitana também se estende ao processo decisório relativo aos assuntos regionais, conforme veremos mais a frente.

Caso contrário seria institucionalizar a inércia sob a justificativa da autonomia do ente inviabilizando os mecanismos criados para a melhor gestão metropolitana e criando condições propícias para a concentração de poderes na medida em que questões regionais exigem uma solução coordenada capaz o suficiente para atender toda a região enquanto respeita a peculiaridade de cada cidade.

${ }^{42}$ Ação Direta de Inconstitucionalidade ${ }^{\circ}$ 1.841-9, p.02. 
Aqui cabe destacar também outra decisão do STF a respeito da competência para editar a lei completar que institui a região metropolitana ou acrescenta municípios a ela.

A Ação Direta de Inconstitucionalidade $n^{\circ} 2.803$ - RS pacificou a questão ao estabelecer que a iniciativa para propor a Lei complementar cabe tanto ao chefe do executivo quanto ao parlamento, pois não implica em alteração na estrutura da máquina administrativa do estado e, portanto, a reserva de iniciativa do artigo 61, $\S 1^{\circ}$, II, e da Constituição da República.

A ideia é facilitar o desenvolvimento das regiões metropolitanas e proporcionar um modo rápido de resolução dos problemas existentes nesses lugares, mas que foram esquecidos há muito tempo pelo legislador. A colocação de mais e mais obstáculos a realização da política urbana aplicada ao âmbito regional, tal como o problema tratado na ADI mencionada acima nada faz além de prejudicar os objetivos do constituinte.

Como se sabe, o capítulo de política urbana foi regulamentado pelo Estatuto das Cidades que buscou trazer para o âmbito municipal as aspirações do Constituinte, mas é omisso quanto a outros assuntos, tornando necessária a edição de uma nova legislação dedicada a aplicar a política urbana de acordo com as especificidades da questão metropolitana, razão pela qual surge o Estatuto da Metrópole.

Criado pelo projeto de Lei $\mathrm{n}^{\circ} 3.640 / 2004$ ele "foi pensado para agilizar a execução dessas ações de cunho urbano-regionais, previstas na Constituição Federal, sem necessidade de regulamentações complementares ${ }^{1143}$.

A legislação assume o papel que até então só era realizado pela doutrina ao conceituar região metropolitana, ali entendida como:

\footnotetext{
43 FIRKOWSKI, Olga. MOURA, Rosa. Estatuto da Metrópole: contribuição ao debate. p.01 Disponívelem:<http://web.observatoriodasmetropoles.net/index.phpoption=com_content\&view=article $\& \mathrm{id}=454 \% 3$ Aestatutometropolecontribuicaoaodebate \&catid=34\%3Aartigos \&Itemid=124\&lang=pt $>$. Acesso em: 20 mar 2016.
} 
Art. $2^{\circ}, \mathrm{V}$ : espaço urbano com continuidade territorial que, em razão de sua população e relevância política e socioeconômica, tem influência nacional ou sobre uma região que configure, no mínimo, a área de influência de uma capital regional, conforme os critérios adotados pela Fundação Instituto Brasileiro de Geografia e Estatística IBGE

Assim como o Estatuto das Cidades, a lei $\mathrm{n}^{\mathrm{o}}$ 13.089/2015 também elegeu seus instrumentos: (i) plano de desenvolvimento urbano integrado; (ii) planos setoriais interfederativos; (iii) fundos públicos; (iv) operações urbanas consorciadas interfederativas; (v) zonas para aplicação compartilhada dos instrumentos urbanísticos previstos no Estatuto das cidades; (vi) consórcios públicos; (vii) convênios de cooperação; (viii) contratos de gestão; (ix) compensação por serviços ambientais ou outros serviços prestados pelo Município à unidade territorial urbana; (x) parcerias público-privadas interfederativas.

Entre os institutos citados, sem dúvida o de maior importância é Plano de Desenvolvimento Urbano Integrado (PDUI), cujo método de aprovação, tempo de vigência e conteúdo estão previstos no Estatuto das Metrópoles.

O Plano deverá ser instituído por lei estadual e aprovado previamente pelo órgão deliberativo da região metropolitana, sendo revisto a cada 10 anos e deverá conter as diretrizes para as funções públicas de interesse comum, o macrozoneamento da unidade territorial urbana, as diretrizes quanto à articulação dos Municípios no parcelamento, uso e ocupação no solo urbano, bem como intersetorial das políticas públicas afetas à unidade territorial urbana e ainda a delimitação das áreas com restrições à urbanização a fim de proteger contra danos ambientais e o patrimônio cultural (art.12).

O PDUI também deverá passar pelo crivo da gestão democrática da cidade prevista na lei $\mathrm{n}^{\circ} 10.257 / 2001$, sendo assegurada a participação popular na elaboração do plano, bem como a participação do Ministério Público $\left(\operatorname{art.} 12 \S 2^{\circ}\right)$. 
A inexistência do Plano de Desenvolvimento Urbano integrado impossibilita a atuação da União com o apoio às ações dos estados (art.14), além de incorrer em improbidade administrativa o governador e o agente público que não elaborou ou aprovou o plano em até três anos contados da instituição da região metropolitana ou das já existentes regiões (art.21).

Por fim, o Estatuto também inova ao estabelecer a gestão plena das regiões metropolitanas consistente na formalização e delimitação mediante lei complementar estadual, na implantação da governança interfederativa própria e na elaboração e aprovação do plano de desenvolvimento urbano integrado, todos já citados anteriormente.

A gestão não pode ser isolada e tão pouco está restrita a esfera dos entes federativos, ela entra em contato com a população direta mente envolvida, proporcionando um mecanismo necessário a gestão democrática das cidades que, aliás, é uma das diretrizes dos Estatutos da Cidade e das Metrópoles.

Obviamente que a simples criação destes mecanismos ou a sua menção no texto legal não são capazes de solucionar os problemas urbanos isoladamente e ainda enfrentam os problemas comuns do meio político, como as divergências partidárias. O próprio Estatuto inviabiliza de certa forma a implantação dos instrumentos ao não conter um fundo responsável por financiar a gestão compartilhada ${ }^{44}$.

Em suma, o Estatuto das metrópoles cumpre o seu papel ao estabelecer as diretrizes da gestão interfederativa, suplantando as dúvidas quanto a execução das funções públicas de interesse comum. Contudo, o sucesso do Estatuto só poderá ser medido com a utilização efetiva dos instrumentos ali previstos.

\footnotetext{
${ }^{44} \mathrm{O}$ texto aprovado pelo Congresso nacional continha uma fonte de recursos em nível metropolitano, no entanto o dispositivo foi objeto de veto.
} 


\section{2) Direito à mobilidade urbana}

O aumento dos automóveis, o crescimento desordenado das cidades e a crescente distância entre os postos de trabalho e os locais de moradia tem cobrado o seu preço em todos os estados do país, principalmente nas regiões metropolitanas onde o fluxo de pessoas e a interdependência de serviços é muito mais evidente.

O resultado são regiões metropolitanas com um sistema de transporte arcaico e incapaz de oferecer uma estrutura de qualidade para o deslocamento diário de seus habitantes, o que se traduz em congestionamentos cada vez maiores e a diminuição das ofertas de emprego e renda para aqueles que moram longe dos eixos de trabalho.

$\mathrm{Na}$ região metropolitana do Rio de Janeiro a oferta de trabalho, lazer e as opções de serviços públicos estão concentradas na zona sul e centro da capital fluminense, fazendo com que $60 \%$ das viagens realizadas diariamente tenham como objetivo a capital, segundo dados da Federação das Indústrias do Estado do Rio de Janeiro ${ }^{45}$. Além disso, dados desta mesma entidade apontam que o congestionamento na região metropolitana poderá chegar a 182 quilômetros em 2022, com um custo de 40 bilhões de reais graças aos prejuízos econômicos causados pela demora no tempo de deslocamento dos habitantes.

Segundo levantamento do Plano Diretor de Transporte Urbano da Região Metropolitana do Rio de Janeiro de $2012^{46}$, a região detinha cerca de 23,4 milhões de viagens diárias, sendo 11,9 milhões no transporte coletivo, 4,4

\footnotetext{
45 FIRJAN. O custo da (i)mobilidade nas regiões metropolitanas do Rio de Janeiro e São Paulo. Disponível em:< http://www.firjan.com.br/publicacoes/publicacoes-de-economia/os-custos-da-imobilidade-nas-regioes-metropolitanas-do-rio-de-janeiro-e-sao-paulo.htm $>$. Acesso em: 13 de abr de 2016.

${ }^{46}$ Idem.
} 
milhões no transporte individual e 7,1 milhões de viagens realizadas a pé ou de bicicleta.

Já na região metropolitana de São Paulo, segundo dados de 2012, se registrava 16,1 milhões de viagens por dia no transporte coletivo e 13,5 milhões no transporte individual, além de 14,3 milhões realizadas de bicicleta ou a pé, com média de $300 \mathrm{~km}$ de congestionamento por dia e perda de 69,4 bilhões de reais ${ }^{47}$.

Na região metropolitana de Goiânia no ano de 2000 foram verificadas um total de 2,2 milhões de viagens diárias, sendo aproximadamente 700 mil realizadas por modos coletivos, o equivalente a 29,8\%. As viagens realizadas de modo individual motorizado correspondiam a 36,4\%, e as feitas a pé ou de bicicleta eram responsáveis por $31,2 \%$ do total ${ }^{48}$.

O Relatório estado da motorização individual no Brasil de 2015 elaborado pelo Observatório das Metrópoles baseado nos dados divulgados pelo Denatran, mostra que nas 17 principais regiões metropolitanas do país estão concentrados $43,6 \%$ de todos os automóveis e $23,3 \%$ das motos, ocasionando a concentração de 35,1 dos veículos para cada habitante, enquanto que no país como um todo esse número é de 23,6 automóveis para cada 100 habitantes. Dos 3,2 milhões de automóveis acrescidos a frota nacional em 2014, aproximadamente $39,7 \%$ estão nas regiões metropolitanas ${ }^{\mathbf{4 9}}$.

Esses dados confirmam os efeitos da falta de planejamento urbano e as dificuldades enfrentadas pelos habitantes das cidades.

\footnotetext{
${ }^{47}$ Idem.

${ }^{48}$ CUNHA, Débora Ferreira da. MELO, Elcileni de Melo Borges Lucelena. A Integração da Rede de Transporte Coletivo da Região Metropolitana de Goiânia in: Funções Públicas de Interesse Comum nas Metrópoles Brasileiras: transportes, saneamento básico e uso do solo. p.244.
} 


\section{1) Direito à cidade, gestão democrática e mobilidade urbana}

Segundo Heliana Comim Vargas, ${ }^{50}$ mobilidade urbana pode ser compreendida como "a capacidade de deslocamento de pessoas e bens no espaço urbano para a realização de suas atividades cotidianas [...] num tempo considerado ideal, de modo confortável e seguro”.

Quando transportamos a ideia de mobilidade urbana para o campo jurídico tal definição torna-se insuficiente enquanto não incorpora os conceitos de direito à cidade, gestão democrática e principalmente da noção de mobilidade urbana enquanto direito. Nessa perspectiva se questiona: o quanto o sistema de mobilidade urbana contribui para uma cidade sustentável? O planejamento foi feito a partir de uma gestão democrática? Qual a relação entre transporte e direito à cidade? São questões que se pretende analisar neste tópico.

Direito à cidade foi originariamente concebido a partir de uma perspectiva filosófica, política e sociológica por Henri Lefebvre ${ }^{51}$, segundo a qual a cidade deve ser construída e conquista pela luta popular de forma a enfrentar e enterrar a concepção capitalista de cidade que transforma o espaço urbano em moeda de troca. Assim, o direito à cidade consiste no "direito de experimentar e usufruir da centralidade urbana no ritmo do valor de uso em oposição ao valor de troca, o que exige necessariamente o rompimento com a

\footnotetext{
${ }^{49}$ Dados extraídos do Relatório estado da motorização individual no Brasil de 2015. Disponível em: < http://www.observatoriodasmetropoles.net/download/automoveis_e_motos2015.pdf>. Acesso em: 23 de abr de 2016.

${ }^{50}$ VARGAS, H. C. (2008). Mobilidade Urbana nas Grandes Cidades. São Paulo, nº. 47, ano XII, p 711, 2008. Disponível em: <http://www.fau.usp.br/depprojeto/labcom/produtos/2008_vargas_imobilidade.pdf>. Acesso em: 15 de abr de 2016.

${ }^{51}$ LEFEBVRE, Henri apud Trindade, Thiago Aparecido. Direitos e cidadania: reflexões sobre o direito à cidade. In: Lua Nova, São Paulo, 87: 139-165, 2012.
} 
lógica capitalista de produção do espaço" ${ }^{52}$. Contudo, qual o conteúdo do direito à cidade no ordenamento jurídico brasileiro?

Ele se enquadra como direito social na medida em que sua plena fruição depende da intervenção estatal e difuso enquanto transindividual, indivisível e cujos titulares são impossíveis de determinar ${ }^{53}$. Quanto ao seu conteúdo Rosângela Lunardelli Cavallazzi assim o define:

"o direito à cidade, expressão do direito à dignidade humana, constitui o núcleo de um sistema composto por um feixe de direitos incluindo o direito à moradia implícita a regularização fundiária -, à educação, ao trabalho, à saúde, aos serviços públicos - implícito o saneamento -, ao lazer, à segurança, ao transporte público, a preservação do patrimônio cultural, histórico e paisagístico, ao meio ambiente natural e construído equilibrado - implícita a garantia do direito a cidades sustentáveis, como direito humano na categoria dos interesses difusos". ${ }^{4}$

No âmbito legislativo o direito à cidade foi reconhecido pela Constituição de 88 ao colocar como objetivo da política urbana o "pleno desenvolvimento das funções sociais da cidade" ${ }^{55}$. Com a edição da lei 10.257/2001 o direito à cidade veio acompanhado do adjetivo "sustentáveis" compreendida como direito à terra urbana, à moradia, ao saneamento ambiental, à infraestrutura urbana, ao transporte e aos serviços públicos, ao trabalho e ao lazer, para as presentes e futuras gerações ${ }^{56}$.

Neste contexto, a mobilidade urbana assume o papel de ligação entre o indivíduo e o direito à cidade, permitindo que ele usufrua de todos os

\footnotetext{
52 TRINDADE, Thiago Aparecido. Obra citada. p.142.

${ }^{53}$ Art.81, Código de Defesa do Consumidor.

${ }^{54}$ CAVALLAZZI, Rosângela Lunardelli. Apud FITTIPALDI, Mariana. Direito à Cidade: diálogo de eqüidade entre o direito à moradia e o direito ao meio ambiente. Disponível em: https://www.google.com.br/url?sa=t\&rct=j\&q=\&esrc=s\&source=web\&cd=2\&cad=rja\&uact=8\&ved=0 ahUKEwiJweHowOnMAhXJhZAKHSKuDjcQFggfMAE\&url=http\%3A\%2F\%2Fwww.dominiopubli co.gov.br\%2Fdownload\%2Fteste\%2Farqs\%2Fcp077268.pdf\&usg=AFQjCNHkG5IL7ol-BcJ59YeEGHJgagaCQ. Acesso em: 06 de maio de 2016.

${ }^{55}$ Art.182, CRFB/88.

${ }^{56}$ Lei $10.257 / 2001$, art. $2^{\circ}$, inciso I.
} 
benefícios que o espaço urbano lhe oferece, ou seja, há um nexo causal entre mobilidade urbana e direito à cidade chamado acessibilidade ${ }^{57}$. Assim:

“[...] o direito à cidade, entendido como a possibilidade de participar das atividades que o meio urbano oferece e como inclusão social das pessoas nas diversas esferas urbanas (produção, comércio, lazer, associações etc.) só pode ser real se houver um adequado acesso aos bens, serviços e atividades que esta oferece. A acessibilidade refere-se à facilidade com que cada pessoa pode superar a distância entre dois lugares e, assim, exercer o seu direito cidadão" ${ }^{58}$

No Brasil é fácil identificar o papel da acessibilidade quando lembramos do processo de urbanização onde, conforme ressalta Ermínia Maricato ${ }^{59}$ as áreas com melhores padrões de urbanização sempre estiveram reservadas para as classes médias e altas, ou seja, aqueles com um poder aquisitivo compatível com o projeto de cidade concebido. Enquanto as classes mais pobres só restaram as áreas mais precárias da cidade e distantes dos grandes centros. A negligência estatal as deixou à margem do mercado formal de habitação, o que por vezes se traduz na distância física dessa parte da população aos aparelhos de lazer, educação e trabalho de qualidade e que muitas vezes estão concentrados nas áreas da cidade consideradas de médio ou alto nível.

Para que seja garantido o acesso a estes lugares se faz necessário um sistema de mobilidade eficiente capaz de atender toda a população. Considerando que o direito a cidades sustentáveis propõe um novo olhar sobre o espaço urbano, certamente inclui a gestão participativa de tudo o que lhe envolve. No tocante a mobilidade urbana tal preceito é seguido pela Lei 12.587/2012 que instituiu a Política Nacional de Mobilidade Urbana:

\footnotetext{
${ }^{57}$ GUTIERREZ, Andrea. Direito à mobilidade. Disponível em: http://cidadeemmovimento.org/direitomobilidade-direitos-e-mobilidade. Acesso em:10 de maio de 2016.

${ }^{58}$ MIRALLES-GÜASCH, C. apud Gutierrez, Andrea. Obra citada.

${ }^{59}$ MARICATO, Ermínia. Metrópoles desgovernadas. Estudos Avançados, v.25, n.71, pp.7-22. 2011.
} 
Art. 15. A participação da sociedade civil no planejamento, fiscalização e avaliação da Política Nacional de Mobilidade Urbana deverá ser assegurada pelos seguintes instrumentos:

I - Órgãos colegiados com a participação de representantes do Poder Executivo, da sociedade civil e dos operadores dos serviços;

II - Ouvidorias nas instituições responsáveis pela gestão do Sistema Nacional de Mobilidade Urbana ou nos órgãos com atribuições análogas;

III - audiências e consultas públicas; e

IV - Procedimentos sistemáticos de comunicação, de avaliação da satisfação dos cidadãos e dos usuários e de prestação de contas públicas.

$\mathrm{Na}$ mobilidade urbana brasileira as políticas de transporte navegam entre o lobby dos fornecedores de tecnologia, produtos e serviços de transporte, pressões dos sindicatos do setor e possíveis contabilidades eleitorais do mapa dos beneficiados, conforme ressalta Raquel Rolnik ${ }^{60}$. E a construção transparente e participativa de um plano de transporte é uma das garantias mais eficazes para evitar a mercantilização excessiva da mobilidade em nossas cidades.

\section{2) Direito à mobilidade urbana na Constituição Federal de 1988}

Conforme foi visto a mobilidade urbana está intrinsicamente ligada ao direito à cidade enquanto um "direito-meio"61, o que a coloca como um dos aspectos fundamentais da política urbana e que, portanto, merece destaque no texto constitucional. Neste tópico será analisada a questão da mobilidade na Constituição de 88 sobre a perspectiva da divisão de competências e do direito material ao transporte.

\footnotetext{
${ }^{60}$ ROLNIK, Raquel. Plano de transporte? Para quê? Disponível em: < http://observatoriodasmetropoles.net/index.php?option $=$ com_k2\&view=item\&id=616\%3Aplano-detransporte\%3F-para-qu\%C3\%AA\%3F-\%7C-raquel-rolnik\&Itemid=164\&lang=pt $>$ Acesso em: 23 de abr de 2016.

${ }_{61}$ ROLNIK, Raquel. Transporte agora é um direito. Disponível em: https://raquelrolnik.wordpress.com/2015/09/21/transporte-agora-e-um-direito. Acesso em: 23 de abr de 2016.
} 
O tema não é novo no direito constitucional brasileiro. A Carta Imperial de 1824 é silente quanto ao assunto, na Constituição de 1891 o único momento em que toca no assunto transporte é ao vedar a tributação no trânsito de um estado para outro ou sobre produtos de outros Estados da República ou estrangeiros, e, bem assim, sobre os veículos de terra e água que os transportarem (art.11). A Constituição de 34 apenas mantém tal disposição (art.17, IX), além de estabelecer a competência privativa da União para legislar sobre tráfego rodoviário interestadual (art.5º, IX). Já o texto de 37 atribui à União a competência para legislar sobre transporte internacional e interestadual (art.16, XI), além de dispor sobre a criação de um conselho de economia para avaliar e aperfeiçoar diversas áreas de produção nacional, incluindo os transportes (art.61, d). A Constituição de 46 mantém a competência legislativa da união sobre tráfego interestadual $\left(\operatorname{art} .5^{\circ}, \mathrm{J}\right)$.

A Constituição Federal de 1967, por sua vez, atribuía à União a competência para legislar sobre tráfego e trânsito nas vias terrestres (art. $8^{\circ}$, XVII, n), sendo conferido aos estados complementar a legislação federal (art. $8^{\circ}$, XVII, parágrafo único), ou seja, tratava-se de uma competência concorrente.

Apesar dos diplomas anteriores terem trazido disposições acerca da competência legislativa sobre transportes, não havia sinais de uma articulação entre os entes federativos e tão pouco a coordenação com uma política urbana. O que só veio ocorrer com a Constituição da República de 88 em seu artigo 182, in verbis:

\footnotetext{
"A política de desenvolvimento urbano, executada pelo Poder Público municipal, conforme diretrizes gerais fixadas em lei, tem por objetivo ordenar o pleno desenvolvimento das funções sociais da cidade e garantir o bem-estar de seus habitantes.
}

Sem dúvida a mobilidade urbana se enquadra nas funções sociais da cidade e tem um papel fundamental no bem-estar de seus habitantes, na medida 
que representa o direito de ir e vir dos indivíduos que deve se dar de forma rápida, segura, eficiente e em conformidade com uma cidade sustentável.

A competência na questão dos transportes também foi alterada em 1988, principalmente para contemplar o município como novo ente federativo e ator principal do desenvolvimento da política urbana. Assim, coube a União instituir diretrizes acerca do desenvolvimento urbano, incluindo-se habitação, saneamento e transportes urbanos (art. 21, XX) - a expressão "transporte urbano" deve ser entendida de forma ampla abrangendo a ideia de mobilidade urbana em geral.

Ao poder municipal foi atribuída a função de organizar e prestar o transporte coletivo (art.30, V), além de legislar sobre assuntos de interesse local e suplementar a legislação federal no que couber.

Neste quadrante, Alexandre de Moraes $^{62}$, Celso Bastos ${ }^{63}$ e Hely Lopes Meirelles $^{64}$ defendem que o transporte interestadual é de competência da União, o transporte dentro do município é de nítida competência deste ente e, considerando que o transporte intermunicipal não é interesse local nem federal, é atribuição do Estados por força da competência residual. Este entendimento encontra-se pacificado na jurisprudência do Supremo Tribunal Federal.

Ocorre que, quando trazemos a questão para o âmbito metropolitano tal posicionamento não pode ser absoluto, pois a mobilidade urbana é uma função pública de interesse comum e, portanto, deve ser decida pelo órgão de governança interfederativa da região metropolitana no qual, segundo o próprio STF, não são permitidas decisões tomadas isoladamente por qualquer dos entes envolvidos, seja Estado ou município.

Até este momento apenas se falava em mobilidade urbana na Constituição no tocante à distribuição de competência. Porém em 2014 a Carta

\footnotetext{
62 MORAES, Alexandre. Competência: trânsito e transporte intermunicipal. p.37. Disponível em: $<$ http://www.revistajustitia.com.br/revistas/3dy1dz.pdf $>$. Acesso em:04 de abr.2016.

${ }^{63}$ BASTOS, Celso. Apud MORAES, Alexandre. Obra citada.

${ }^{64}$ Meirelles, Hely Lopes. Apud MORAES, Alexandre. Obra citada.
} 
foi alterada através da emenda $n^{\circ} 82$ que modificou ou artigo 144 trazendo duas importantes mudanças. A primeira delas definiu que cabe aos estados e municípios zelar pela segurança viária - entendida pelo legislador como "preservação da ordem pública e da incolumidade das pessoas e do seu patrimônio nas vias públicas" - enquanto parte da segurança pública. A segunda alteração vem do reconhecimento do direito do cidadão à mobilidade eficiente.

Contudo, a mudança mais significativa veio no ano seguinte com a PEC $n^{\circ}$ 90/2011 que alterou o artigo $6^{\circ}$ da Constituição para incluir o transporte como um direito social, fazendo com que ele figure junto ao direito à educação, saúde, trabalho, lazer, segurança, previdência social, proteção à maternidade, proteção à infância, assistência aos desamparados, bem como os direitos à moradia, alimentação.

A inserção do transporte no rol dos direitos sociais não é apenas uma alteração gramatical, ela possui efeitos práticos já que agora o transporte está submetido ao regime diferenciado próprio dos direitos sociais, a proteção privilegiada contra intervenções por parte do poder público e condição de limites materiais ao poder constituinte reformador.

$\mathrm{O}$ direito ao transporte é um direito fundamental enquanto representa o próprio direito de ir e vir e como um caminho para o exercício de outras garantias constitucionais como o acesso ao trabalho, ao lazer, à moradia entre outros. Além disso, a inclusão do transporte no capítulo dos direitos sociais também tem efeito prático, obrigando a União a destinar recursos do orçamento anual para a mobilidade urbana, já que como direito social ele pressupõe a intervenção do Estado para sua concretização.

Como visto, a mobilidade faz parte do planejamento urbano previsto no artigo 182. O mesmo dispositivo que deu causa a regulamentação trazida pelo Estatuto da Cidade e o Estatuto das Metrópoles também possibilitou a criação da Política Nacional de Mobilidade Urbana. 


\section{3) Planejamento e mobilidade urbana}

Estabelecida a importância do direito à mobilidade urbana surge a necessidade de um planejamento efetivo para a sua execução. Um destes instrumentos veio com a Política nacional de mobilidade urbana.

Em 1989 foi proposto o projeto de lei $n^{o} 4.203 / 1989$ com o intuito de apresentar normas gerais do sistema nacional de transporte coletivo urbano de passageiros. A este projeto foram apensados os PLs nº 870/1991, 1.777/1991 e 2.594/1992 propostos posteriormente, porém todos eles permaneceram anos sem movimentação na Câmara dos Deputados e foram arquivados em $1995^{65}$.

Ainda na década de 90, surgiu o Projeto de Lei $n^{\circ}$ 694/1995 e a ele foram apensados os PLs n ${ }^{\circ} 1.974 / 1996$ e 2.234/1999. Curioso é que os novos projetos de lei seguiram a mesma tendência dos projetos já arquivados na Câmara de Deputados ao tratar da mobilidade urbana restrita ao transporte coletivo.

Neste ínterim foi promulgada a Lei $\mathrm{n}^{\circ}$ 10.257/2001 também conhecida como Estatuto das Cidades. Responsável por estabelecer as orientações do planejamento urbano, a lei incluiu o transporte como diretriz da política urbana, além de estabelecer a obrigatoriedade de planos de transporte urbano integrado - compatíveis com os respectivos planos diretores - para municípios com mais de 500 mil habitantes.

A Resolução nº 34/2005 do Conselho das Cidades, órgão vinculado ao Ministério das Cidades, foi a responsável por prever o conteúdo obrigatório dos planos diretores de mobilidade urbana que devem: i) garantir a diversidade das modalidades de transporte, respeitando as características das cidades,

\footnotetext{
${ }^{65}$ INSTITUTO DE PESQUISA ECONÔMICA APLICADA - IPEA. Comunicado 128 - A nova Lei de Diretrizes da Política Nacional de Mobilidade Urbana. Disponível em: http://www.ipea.gov.br/portal/images/stories/PDFs/comunicado/120106_comunicadoipea128.pdf. Acesso em: 13 de abr de 2016.
} 
priorizando o transporte coletivo, que é estruturante sobre o individual, os modos não motorizados e valorizando o pedestre; ii) garantir que a gestão da Mobilidade Urbana ocorra de modo integrado com o Plano Diretor Municipal; iii) respeitar as especificidades locais e regionais; e iv) garantir o controle da expansão urbana, a universalização do acesso à cidade, a melhoria da qualidade ambiental, e o controle dos impactos no sistema de mobilidade gerados pela ordenamento do uso do solo.

Enquanto a lei $\mathrm{n}^{\mathrm{o}} 10.257 / 2001$ falava apenas superficialmente de uma política de transporte, o Projeto de Lei no 694/1995 recebeu um novo apenso: o PL no 1.687/2007 que deu uma nova perspectiva ao tratar a mobilidade urbana como algo que vai além do transporte coletivo. $\mathrm{O}$ projeto foi finalmente encaminhado ao Senado Federal em 2010 onde recebeu o $n^{\circ}$ 166/2010. Somente em 2012 o projeto foi votado e aprovado, dando origem a lei $\mathrm{n}^{\mathrm{o}}$ 12.587/2012 criando o marco regulatório da mobilidade urbana.

Já em seu primeiro artigo a lei reafirma o disposto no Estatuto das Cidades ao dizer que a política nacional de mobilidade urbana é um instrumento da política de desenvolvimento urbano e que deve atender aos preceitos da Lei $\mathrm{n}^{\mathrm{o}} 10.257 / 2001$. O diploma também conceitua o sistema de mobilidade urbana como "conjunto organizado e coordenado dos modos de transporte, de serviços e de infraestruturas que garante os deslocamentos de pe ssoas e cargas no território do Município" ${ }^{66}$.

A Lei prossegue citando os princípios norteadores da política nacional de mobilidade urbana (art. $\left.5^{\circ}\right)$ : i) acessibilidade universal; ii) desenvolvimento sustentável; iii) equidade no acesso ao transporte público coletivo; iv) eficiência, eficácia e efetividade na prestação dos serviços de transporte e na circulação urbana; v) segurança nos deslocamentos; vii) justa distribuição dos benefícios e ônus no uso dos diferentes modos; viii) equidade no uso do espaço

${ }^{66}$ Art. $3^{\circ}$ da Lei no $12.587 / 2012$. 
público de circulação, vias e logradouros; e ix) gestão democrática e controle social do planejamento e avaliação da Política Nacional de Mobilidade Urbana.

O marco também segue a ideia de priorizar os transportes não motorizados sobre os motorizados e os coletivos sobre os individuais, com a diminuição dos custos ambientais, sociais e econômicos no deslocamento de cargas e pessoas e a integração entre os modais de transporte ${ }^{67}$. A lei $\mathrm{n}^{\mathrm{o}}$ 12.587/2012 também caminha no mesmo sentido do Estatuto das Cidades ao postular como seus objetivos a redução das desigualdades e a promoção da inclusão social, proporcionar a melhoria nas condições da população urbana, principalmente no que se refere ao quesito acessibilidade e promover o desenvolvimento sustentável.

Quanto ao aspecto prático a legislação repisa as competências estabelecidas pela Constituição e atribui novas funções aos entes, além de apresentar dois pontos fundamentais, quais sejam: os instrumentos de gestão e os planos municipais de mobilidade urbana.

Primeiramente, a política nacional especifica as atribuições básicas dos entes federativos quanto à mobilidade urbana, assim é competência da União prestar assistência técnica e financeira aos estados e municípios, além de organizar os serviços de transporte público interestadual de caráter urbano entre outros. Aos Estados, compete organizar e prestar o transporte público intermunicipal, em especial nos casos de aglomerações urbanas e regiões metropolitanas. Já aos Municípios foi atribuída a tarefa de planejar e executar a Política Nacional de Mobilidade Urbana, prestar direta ou indiretamente os serviços de transporte público urbano e capacitar seus agentes ${ }^{68}$.

Por sua vez, o artigo 23 da lei 12.587/2012 estipula os instrumentos que poderão ser usados pelos entes federativos na efetivação da política de mobilidade urbana, sendo eles: I - restrição e controle de acesso e circulação,

\footnotetext{
${ }^{67}$ Art. $6^{\circ}$ da Lei $n^{\circ} 12.587 / 2012$.

${ }^{68}$ Arts. 16-18 da Lei n ${ }^{\circ} 12.587 / 2012$;
} 
permanente ou temporário, de veículos motorizados em locais e horários predeterminados; II - estipulação de padrões de emissão de poluentes para locais e horários determinados, podendo condicionar o acesso e a circulação aos espaços urbanos sob controle; III - aplicação de tributos sobre modos e serviços de transporte urbano pela utilização da infraestrutura urbana, visando a desestimular o uso de determinados modos e serviços de mobilidade, vinculando-se a receita à aplicação exclusiva em infraestrutura urbana destinada ao transporte público coletivo e ao transporte não motorizado e no financiamento do subsídio público da tarifa de transporte público; IV dedicação de espaço exclusivo nas vias públicas para os serviços de transporte público coletivo e modos de transporte não motorizados; V - estabelecimento da política de estacionamentos de uso público e privado, com e sem pagamento pela sua utilização, como parte integrante da Política Nacional de Mobilidade Urbana; VI - controle do uso e operação da infraestrutura viária destinada à circulação e operação do transporte de carga, concedendo prioridades ou restrições; VII - monitoramento e controle das emissões dos gases de efeito local e de efeito estufa dos modos de transporte motorizado, facultando a restrição de acesso a determinadas vias em razão da criticidade dos índices de emissões de poluição; VIII - convênios para o combate ao transporte ilegal de passageiros; e IX - convênio para o transporte coletivo urbano internacional nas cidades definidas como cidades gêmeas nas regiões de fronteira do Brasil com outros países, observando o art. 178 da Constituição Federal.

O diploma também retornou a questão dos planos de mobilidade urbana como fez o Estatuto das Cidades, porém mudando o critério, já que o plano passa a ser obrigatório nos municípios com mais de 20.000 habitantes, devendo contemplar os serviços de transporte público coletivo, as infraestruturas do sistema de mobilidade urbana a acessibilidade para pessoas com deficiência e restrição de mobilidade, integração dos modos de transporte público, 
delimitação das áreas de estacionamento, sistemática de revisão dos planos em no máximo dez anos, entre outras estipulações.

Os municípios sem sistema de transporte público, seja coletivo ou individual, também devem ter seu plano de mobilidade urbana, cujo conteúdo terá foco no planejamento do transporte não motorizado e nos deslocamentos a pé e por bicicleta.

Foi estabelecido o prazo de três anos a partir da vigência da lei para a criação e integração dos planos de mobilidade aos planos diretores existentes ou em elaboração, nos municípios que porventura ainda não o tenham aprovado ou integrado. Caso a determinação não seja cumprida, estes entes ficam impedidos de receber recursos orçamentários federais destinados à mobilidade urbana para parcerias firmadas após a vigência da lei.

Em 2015, o prazo previsto pela lei $12.587 / 2012$ para a aprovação dos planos de mobilidade urbana findou. Contudo, segundo dados do Ministério da Cidade, apenas 1.317 municípios do total de 3.325 do s entes com mais de cinquenta mil habitantes deram alguma resposta - apenas $5 \%$ possuem o plano e outros $29 \%$ ainda estão em elaboração ${ }^{69}$.

Diante disso, já existe o projeto de lei $n^{\circ} 7.898 / 2014$ de origem da Câmara dos Deputados que atualmente está em tramitação no Senado Federal para prorrogar o prazo de elaboração dos planos até 2018. Alega-se que os municípios não dispõem de recurso para a execução do PDMU e que precisariam de mais tempo para adequar suas legislações. Certo é que a suposta falta de recursos não é o único obstáculo encontrado, os municípios também estão em atraso com outro instrumento do planejamento urbano os planos diretores, pois os PNMUs devem ser a eles integrados. Como integrar um plano a outro que não existe?

\footnotetext{
${ }^{69}$ Menos de 30\% das principais cidades brasileiras possuem Plano de Mobilidade Urbana. Disponível em:

$<$ http://www.ntu.org.br/novo/NoticiaCompleta.aspx?idNoticia=449\&idArea=10\&idSegundoNivel=10 6>. Acesso em: 21 de abr. de 2016.
} 
Segundo levantamento do IBGE o país possui 5.570 municípios $^{70}$, deste número 4.191 possuem alguma estrutura de planejamento urbano, 2.786 possuem plano diretor, 2.783 estão sem o plano e 691 em elaboração. Se considerarmos que a lei 12.587/2012 determina que o plano de mobilidade urbana deve ser plenamente integrado ao plano diretor, perceberemos que o problema é muito maior e está longe de ser solucionado.

Quando falamos de mobilidade urbana nas regiões metropolitanas temos: i) Plano Diretor obrigatório para municípios com mais de 20.000 habitantes ou integrantes de regiões metropolitanas que deverá atender as diretrizes fixadas no Estatuto da Cidade, entre elas o transporte; ii) Plano de Mobilidade Urbana, inicialmente concebido pela lei 10.257/2001 obrigatório para municípios com mais de 500 mil habitantes e, com o advento da Política Nacional de Mobilidade Urbana, para cidades com mais de 20.000 habitantes, devendo estar plenamente integrado com o Plano Diretor; iii) Plano de Desenvolvimento Urbano Integrado previsto pelo Estatuto da Metrópole o qual conterá as diretrizes para as funções públicas de interesse comum, entre elas a mobilidade urbana.

\footnotetext{
${ }^{70}$ IBGE, Diretoria de Pesquisas, Coordenação de População e Indicadores Sociais, Pesquisa de Informações Básicas Municipais 2015. Disponível em: http://www.ibge.gov.br/home/estatistica/economia/perfilmunic. Acesso em: 21 de abri de 2016.
} 


\section{3) Efeitos da implantação do corredor BRT TransBrasil na Região Metropolitana do Rio de Janeiro}

No desenvolvimento urbano das metrópoles brasileiras percebe-se a expansão de espaços urbanos ao redor de núcleos centrais cuja relevância vem de um processo histórico, político e cultural de concentração de residência das classes dominantes, bem como grande parte dos postos de trabalho e oferta de serviços ${ }^{71}$.

$\mathrm{Na}$ formação da metrópole do Rio de Janeiro não foi diferente. A construção de novos bairros (Copacabana, Gávea, Ipanema, Jardim Botânico, Lagoa, Tijuca e Vila Isabel) voltados para as classes mais altas e que recebiam, quase na totalidade, todos os investimentos em infraestrutura, sejam públicos ou privados, restando a população menos abastada a área central da cidade.

Com a "higienização" promovida na gestão Pereira Passos e a destruição das moradias localizadas na área central da cidade, as pessoas atingidas são obrigadas a se deslocar para os subúrbios em um ritmo cada vez mais crescente e com maiores distâncias, lugares antes ocupados pela produção cafeeira vão dando lugar a novas indústrias, iniciando o processo de urbanização da região metropolitana.

Porém somente em 1974 ocorreu a institucionalização da região metropolitana do Rio com a edição da lei federal n²0 que uniu o Estado do Rio de Janeiro e o Estado da Guanabara. Na época a região contava com 14 municípios, mas atualmente são 21 municípios: Rio de Janeiro, Belford Roxo, Duque de Caxias, Guapimirim, Itaboraí, Japeri, Magé, Maricá, Mesquita, Nilópolis, Niterói, Nova Iguaçu, Paracambi, Queimados, São Gonçalo, São João de Meriti, Seropédica, Tanguá, Itaguaí, Rio Bonito e Cachoeiras de

\footnotetext{
${ }^{71}$ RODRIGUES, Juciano Martins. Transformações urbanas e crise da mobilidade urbana no Brasil hipóteses sobre o caso do Rio de Janeiro no contexto dos megaeventos. Disponível em: http://www.observatoriodasmetropoles.net/index.php?option=com_k2\&view=item\&id=736\%3Acrisede-mobilidade-megaeventos-e-rio-de-janeiro\&Itemid=165\&lang=pt. Acesso em: 06 de maio de 2016.
} 
Macacu, totalizando 12, 2 milhões de habitantes e uma área de $6.737 \mathrm{Km}^{2}{ }^{72}$ Veja o mapa a seguir:

Figura 1: região metropolitana do Rio de Janeiro

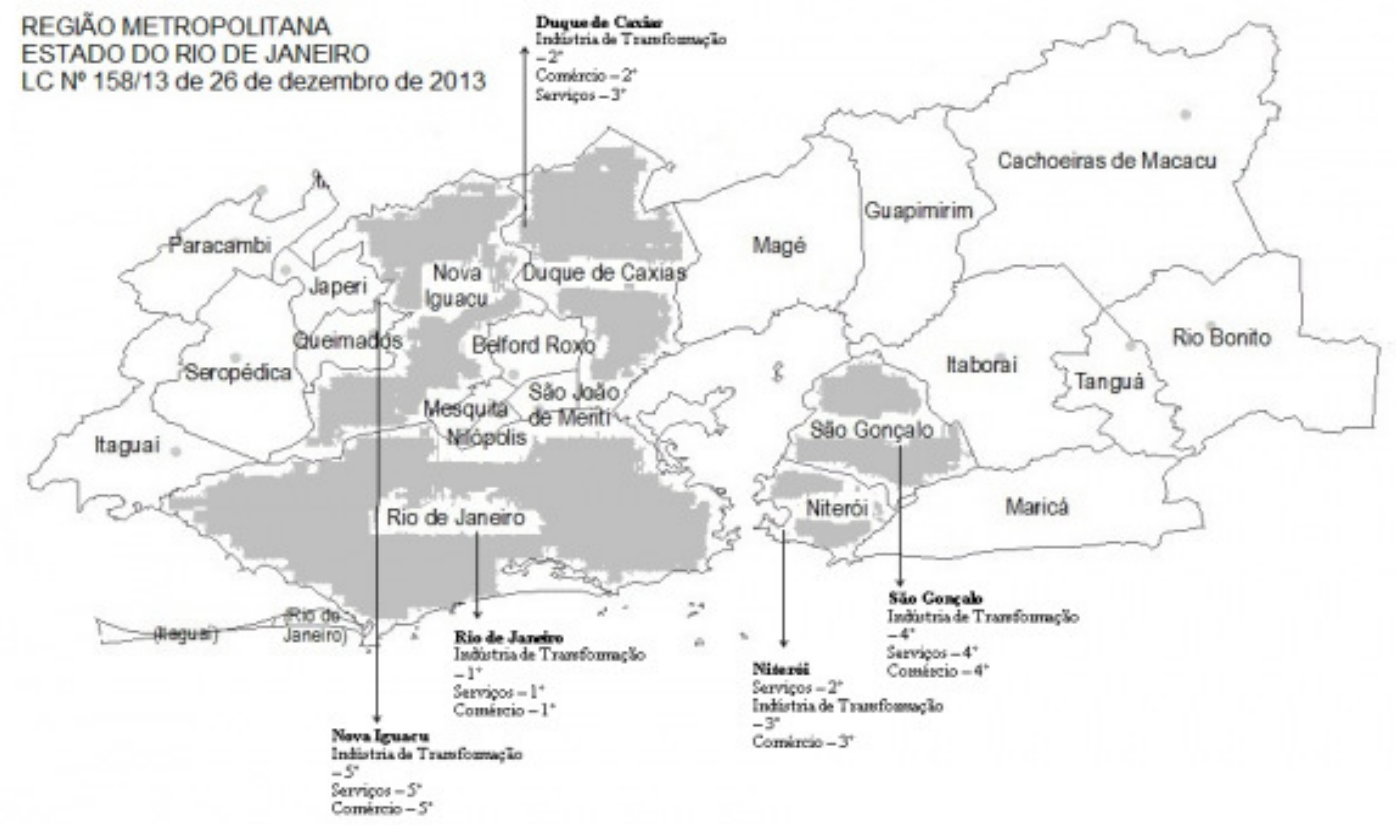

Fonte: http://espacoeconomia.revues.org/1345

Quanto à gestão metropolitana, a RM do Rio de Janeiro ainda não possui o Plano Diretor Urbano Integrado ${ }^{73}$. Na década de 70 , foi criada a Fundação para o Desenvolvimento da Região Metropolitana do Rio de Janeiro (FUNDREN) composta por técnicos responsáveis pelo planejamento urbano da Região Metropolitana do Estado. Durante seu funcionamento a FUNDREM teve seu desempenho comprometido pelas disputas políticas entre os municípios e o Estado que inviabilizavam muitos dos projetos apresentados,

72 CEPERJ. Disponível em: http://www.ceperj.rj.gov.br/ceep/info_territorios/divis_regional.html. Acesso em: 13 de maio de 2016.

${ }^{73}$ A criação obrigatória do Plano Diretor de Desenvolvimento Urbano Integrado foi prevista pelo art. $9^{\circ}$, inciso I do Estatuto das metrópoles. 
até que a entidade foi extinta em $1989^{74}$. Atualmente, o que temos em termos de instâncias metropolitanas é o Comitê Executivo de Estratégias Metropolitanas e a Câmara Metropolitana de Integração Governamental. O primeiro foi criado pelo Decreto estadual 42.832/2011 para propor política públicas para a região metropolitana do Rio de Janeiro "visando promover a gestão dos assuntos de caráter metropolitano, integrar suas demandas e planejar e executar as políticas públicas de interesse comum relativas ao desenvolvimento da região"75 e é composto por representantes das secretarias de Estado de Obras, Desenvolvimento Regional, Planejamento e Gestão, Fazenda, Habitação, Transporte, Ambiente, Assistência Social e Direitos Humanos e da Casa Civil, além do apoio da Universidade Estadual do Rio de Janeiro (Uerj).

Com a edição do decreto estadual no 44.439/2013, o Comitê Executivo de Estratégias Metropolitanas passa a ter um papel somente consultivo para auxiliar o comitê de coordenação criado pela lei acima mencionada e que é composto por representantes da vice-governadoria, da secretaria de estado de obras, da secretaria de estado de planejamento e gestão e da secretaria de estado da Fazenda.

Mesmo após o julgamento da ADI 1842/ RJ citada neste trabalho, a estrutura do órgão permanece a mesma, ou seja, contrária frontalmente a decisão do STF, pois não há participação dos municípios integrantes da região metropolitana.

Já a Câmara Metropolitana de Integração Governamental foi criada em 2014 e é composta pelo governador e os prefeitos dos 21 das cidades da RMRJ cujas atribuições são a coordenação das funções públicas metropolitanas de

\footnotetext{
${ }^{74}$ FONTES, Angela MM; DE ARAÚJO, Valdemar F. Gestão metropolitana, fragmentação política e processo de sub-regionalização: as tendências político-institucionais da questão metropolitana do Estado do Rio de Janeiro.Anais: Encontros Nacionais da ANPUR, v. 6, 2012.

75 Governo do Estado do Rio de Janeiro. Disponível em: http://www.mi.gov.br/c/document_library/get_file?uuid=c87abc18-1d3e-4d0d-ba18057e56806a21\&groupId=10157. Acesso em: 14 de maio de 2016.
} 
interesse comum ao estado e aos municípios (transporte, uso do solo, saneamento, saúde, educação, etc.), compatibilizar as diversas propostas de ação que incidem no território metropolitano, criar uma estrutura legal e institucional para a Região Metropolitana e Intermediar a cooperação entre os diversos níveis de governo da região ${ }^{76}$

Somente em 2015, com o fim do prazo da modulação dos efeitos da ADI é que foi enviada à Assembleia Legislativa o projeto de lei redefinindo a estrutura da RMRJ.

Quanto à mobilidade urbana na região metropolitana do Rio de Janeiro temos o Plano Diretor de Transportes Urbanos - PDTU. Formulado pela secretaria estadual de transportes em 2003, o plano visa orientar o Governo do Estado na execução das políticas públicas referentes ao transporte, bem como estabelecer a forma de investimentos em infraestrutura viária e sistemas de transporte coletivo, além de definir modelos operacionais e tarifários. O plano foi atualizado para 2015 com o objetivo de incorporar as modificações feitas para os megaeventos ocorridos na cidade do Rio e traçar os rumos futuros do transporte regional.

Essa atualização foi conduzida por um consórcio contratado e os municípios da RMRJ deverão ajustar seus planos municipais de mobilidade urbana ao PDTU.

Em uma região que concentra $74 \%$ da população total do estado e com a continuação da lógica de alocação de investimentos em áreas isoladas do município do Rio de Janeiro, as melhores condições de trabalho e lazer estão

\footnotetext{
${ }^{76}$ Governo do Estado do Rio de Janeiro. Criação da Câmara Metropolitana de Integração Governamental. Disponível em: https://www.google.com.br/url?sa=t\&rct=j\&q=\&esrc=s\&source=web\&cd=1\&cad=rja\&uact $=8 \& v e d=0$ ahUKEwi3rbW_iOLMAhVGjZAKHTRLCA8QFggcMAA\&url=http\%3A\%2F\%2Fwww.rio.rj.gov.br \%2Fdlstatic\%2F10112\%2F5333332\%2F4139328\%2F29GestaoMetropolitanaGovEstado012015.pdf\& usg=AFQjCNFP0leqacJ4UUcm9wplsz_j8aNw\&sig2=ULcNOdwNidG3BSWit0Qi5w>. Acesso em: 14 de maio de 2016.
} 
concentradas em um pequeno espaço em comparação com a área total da metrópole: o município do Rio de Janeiro ${ }^{77}$.

Assim, ações de reformulação na mobilidade urbana - considerada uma função pública de interesse comum segundo o decreto estadual $n^{\circ} 44.439 / 2013$ - na cidade do Rio de Janeiro poderá afetar diretamente toda a estrutura da região quanto a acessibilidade de seus habitantes aos bens e serviços concentrados naquele município, não podendo ser desconsiderada em uma gestão metropolitana.

No presente capítulo se pretende avaliar os impactos do corredor BRT TransBrasil na região metropolitana do Rio de Janeiro a partir dos pressupostos colocados no decorrer dos capítulos anteriores, em especial: a gestão metropolitana, o direito à mobilidade urbana e o direito à cidade.

\section{1) O projeto}

O discurso oficial de se criar a "melhor cidade do hemisfério sul para se viver, trabalhar e conhecer"78 aliada com a realização dos megaeventos é até hoje a bandeira levantada pela gestão do município do Rio de Janeiro para a implantação de diversos projetos, principalmente na mobilidade urbana.

$\mathrm{Na}$ cidade mais congestionada do Brasil e a $4^{\mathrm{a}}$ em escala mundial, ${ }^{79}$ a reformulação no sistema de transporte está concentrada na criação de BRTs (do inglês Bus Rapid Transit), um desses corredores é o que pretendemos estudar neste capítulo: o BRT TransBrasil.

\footnotetext{
${ }^{77}$ Segundo dados do IBGE o município do Rio de Janeiro possui cerca de 1.199,828 Km². Disponível em: http://cidades.ibge.gov.br/xtras/perfil.php?codmun=330455. Acesso em: 14 de maio de 2016.

78 Plano estratégico da prefeitura da cidade do Rio de Janeiro. Disponível em: http://www.conselhodacidade.com/v3/pdf/planejamento_estrategico_13-16.pdf. Acesso em: 11 de maio de 2016.

79 Rio de Janeiro é a cidade mais congestionada do Brasil. Disponível em: http://www.mundosustentavel.com.br/2016/03/rio-de-janeiro-e-a-cidade-mais-congestionada-dobrasil/. Acesso em: 11 de maio de 2016.
} 
Trata-se de um corredor expresso de ônibus articulados a ser implantado ao longo da Avenida Brasil, partindo do bairro de Deodoro até o Centro da cidade. A obra foi dividida em duas etapas: a primeira compreenderá o trecho que vai do Caju, através da Avenida Rodrigues Alves, para a Avenida Presidente Vargas até a altura da Rua Uruguaiana, a segunda etapa percorrerá o sentido contrário da Avenida Presidente Vargas até o Caju através da Avenida Francisco Bicalho ${ }^{80}$.

Ambas as linhas passarão por um terminal que deverá ser construído na altura do gasômetro onde ocorrerá a integração com uma das linhas do VLT, além dos terminais Américo Fontenelle e Procópio Ferreira localizados ao redor da Central, nos quais parte das linhas existentes se tornaram alimentadoras do sistema BRT.

Segundo a Prefeitura da Cidade do Rio de Janeiro, "o BRT Transbrasil vai estabelecer um sistema de transporte de alta capacidade entre as zonas Oeste, Norte e o Centro da cidade" ${ }^{\text {"1 }}$, o corredor deverá terá cerca de 32 quilômetros, com sete terminais Deodoro, Margaridas (intersecção com a BR116 Rio - São Paulo), Missões (intersecção com a BR040 Rio - Juiz de Fora), Fundão, Gasômetro, Américo Fontenelle e Presidente Vargas), e 20 estações. A expectativa da prefeitura é atender 820 mil passageiros por dia, tornando o BRT TransBrasil o maior do mundo. Veja como ficará o trajeto:

\footnotetext{
${ }^{80}$ Mobilidade Urbana. Secretaria Municipal de Obras. Disponível em: http://www.rio.rj.gov.br/web/smo/exibeconteudo?id=1030921. Acesso em: 10 de maio de 2016.

${ }^{81}$ Mobilidade Urbana. Secretaria Municipal de Obras. Idem.
} 
Figura 2: Trajeto BRT TransBrasil

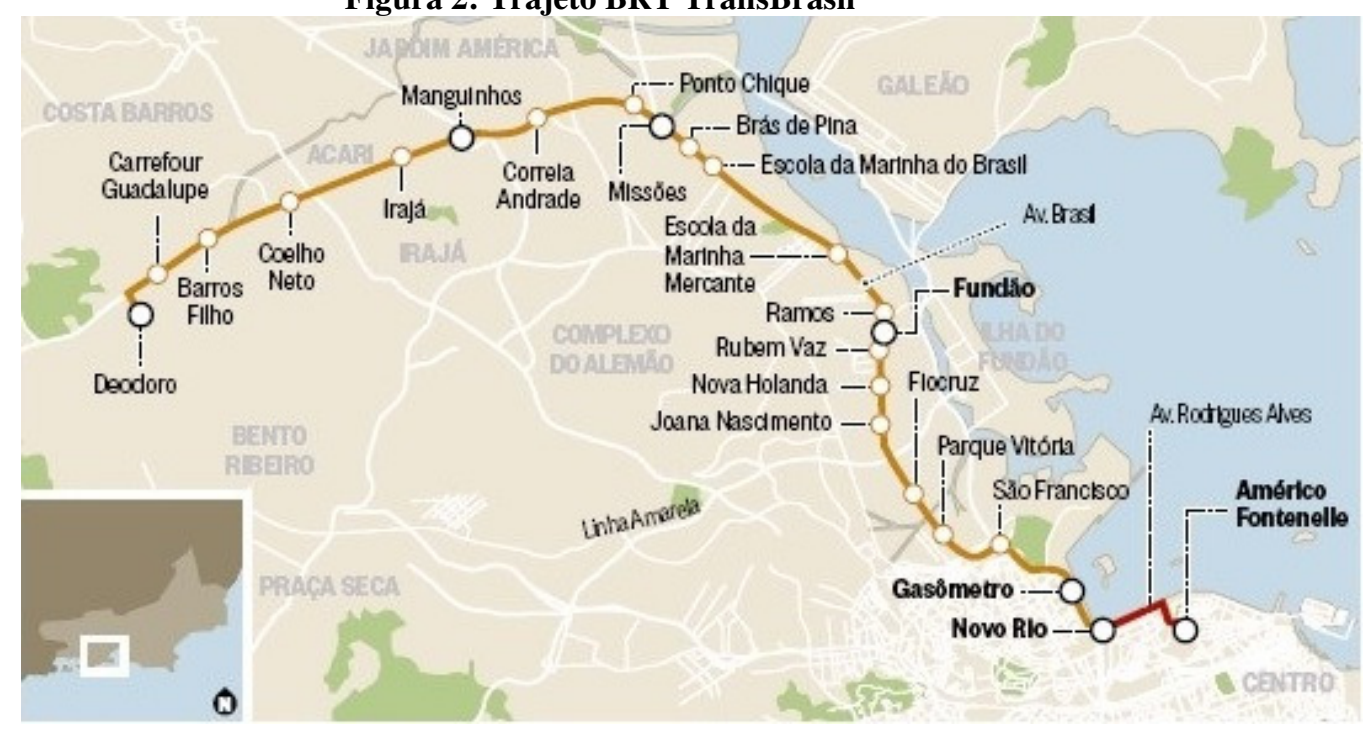

Fonte: Prefeitura da Cidade do Rio de Janeiro

Com a construção do projeto, a TransBrasil se juntará aos BRTs Transcarioca, Transoeste e Transolímpica formando um anel rodoviário de 155 quilômetros, proporcionando, segundo a gestão municipal, um "sistema proporciona uma mobilidade mais inteligente, dinâmica, segura e sustentável para a população carioca" ${ }^{\prime 2}$.

${ }^{82}$ Mobilidade Urbana. Secretaria Municipal de Obras. Idem. 
Figura 3: Configuração atual dos corredores BRTs

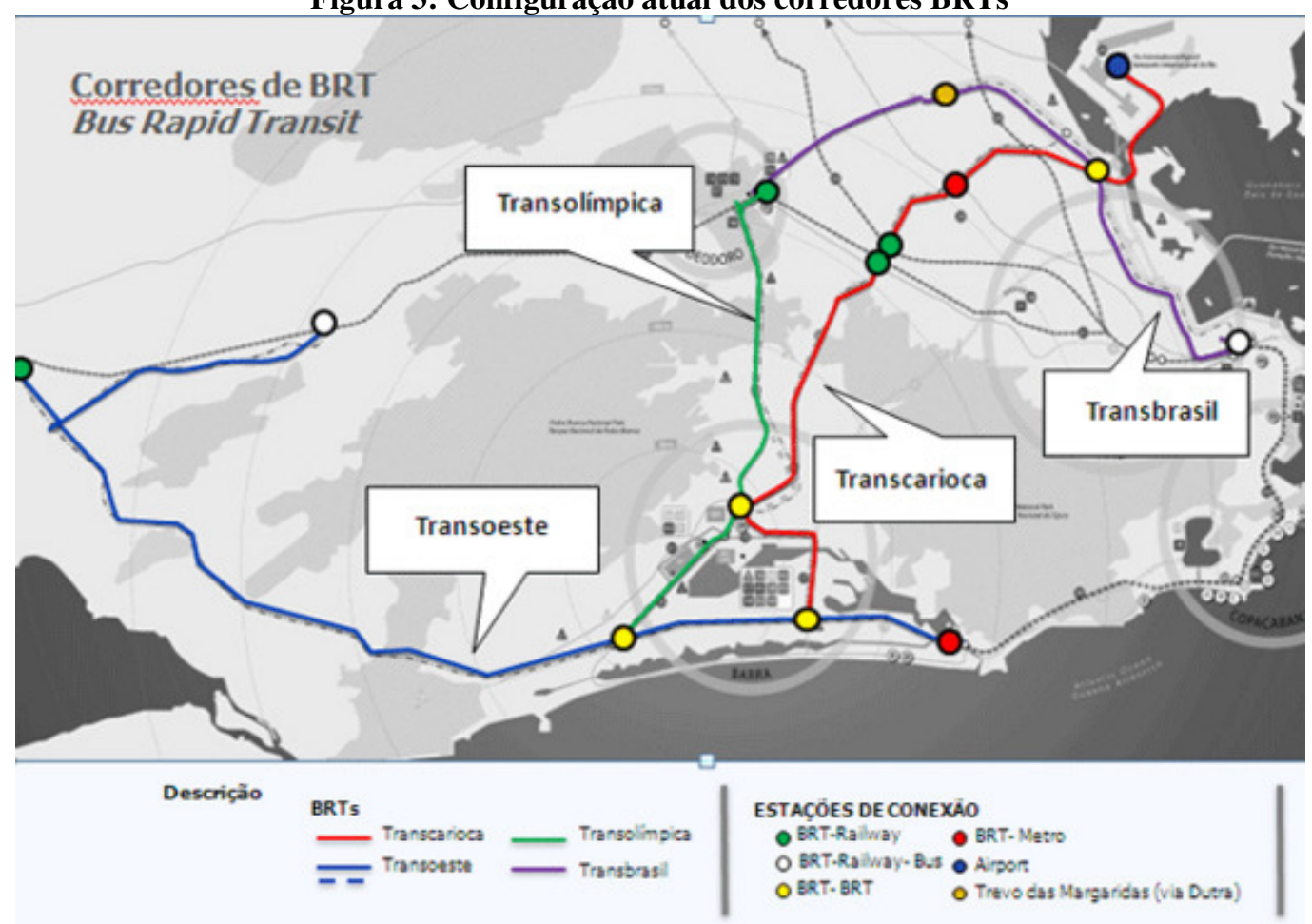

Fonte: http://www.caurj.gov.br/wp-content/uploads/2014/03/IMAGEM-02.Mapa-da-Trans1.jpg.

A construção dos corredores BRTs por toda a cidade foi pensada como um "pacote olímpico" para atender a população do Rio e melhorar a infraestrutura da malha urbana. No caso dos corredores Transoeste, Transcarioca e Transolímpica os impactos são suportados quase que totalmente pela população do município responsável pelo projeto, mas o mesmo não se pode dizer do BRT TransBrasil como veremos a seguir.

\section{2) Interesse local ou metropolitano? Os aspectos jurídicos da} implantação do BRT TransBrasil para a região metropolitana do Rio de Janeiro

Sabemos que a mobilidade urbana possui status de função pública de interesse comum nas regiões metropolitanas brasileiras, o que obriga o gestor público a analisar todas as obras e projetos que estão sendo implantados na 
base territorial da metrópole inseridos no tema, ainda que não ultrapassem os limites físicos da cidade no qual está sendo construído.

Isto porque podem ter efeitos que vão muito além das fronteiras municipais atingindo grande parte da população da RM, considerando as características de formação daquele espaço urbano.

Para tentar responder à pergunta título deste tópico será analisada a obra do BRT TransBrasil a partir de duas perspectivas. A primeira delas considera o alcance de projeto a partir do movimento pendular da região metropolitana, dos diplomas legais citados ao longo do texto sobre gestão das metrópoles e execução das funções públicas de interesse comum, do Plano Diretor de Transporte Urbano, o direito à mobilidade urbana e o direito à cidade, colocando a região metropolitana do Rio de Janeiro em perspectiva.

Relembrando a caracterização feita por Diogo de Figueiredo Moreira Neto, é considerado interesse local aquele que é interno às cidades, territorialmente limitado ao município, cujos efeitos não repercutem externamente e simultaneamente oposto a regional e nacional.

A luz deste conceito o BRT TransBrasil, inicialmente, a obra poderia ser considerada de competência da cidade do Rio de Janeiro, já que interna ao município e o trajeto do corredor não ultrapassa seus limites físicos, além disso sua execução também estaria de acordo com o artigo 30, V da Constituição de 88 que prevê a competência do ente municipal para organizar e prestar o transporte coletivo local. Entretanto, se analisarmos os requisitos seguintes veremos que seus efeitos repercutem além de suas fronteiras e que não se pode dizer que é simultaneamente oposto ao interesse regional.

Isto porque a avaliação do alcance e impacto de projetos de transporte vai além da fixação dos limites do percurso da obra. A própria questão da mobilidade urbana "envolve também problemas de organização espacial das atividades humanas, de adaptação de investimentos, das necessidades e 
aspirações da população quanto ao local de residência e trabalho" ${ }^{83}$, ou seja, está diretamente ligada ao processo de urbanização do local.

Neste ponto reside a gênese do problema, o que faz com que o BRT TransBrasil cause impactos que vão muito além da comunidade local. Em decorrência do desenvolvimento urbano da cidade do Rio de Janeiro e dos investimentos isolados em seu território ao longo dos $\operatorname{anos}^{84}$, as ofertas de trabalho, emprego, lazer dentro da região metropolitana estão em sua maioria concentradas no município citado, conforme demonstram os gráficos abaixo:

Figura 4: Empregos na indústria na região metropolitana do Rio de Janeiro

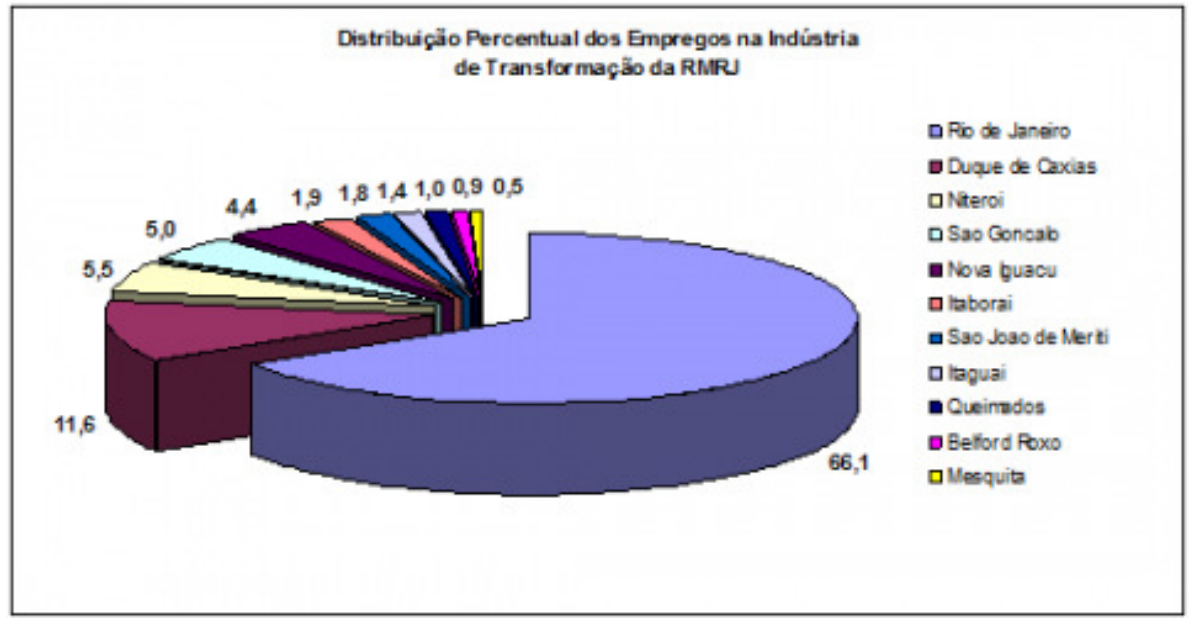

Fonte: RAIS/MTE

Figura 5: Empregos no setor de serviços na região metropolitana do Rio de Janeiro

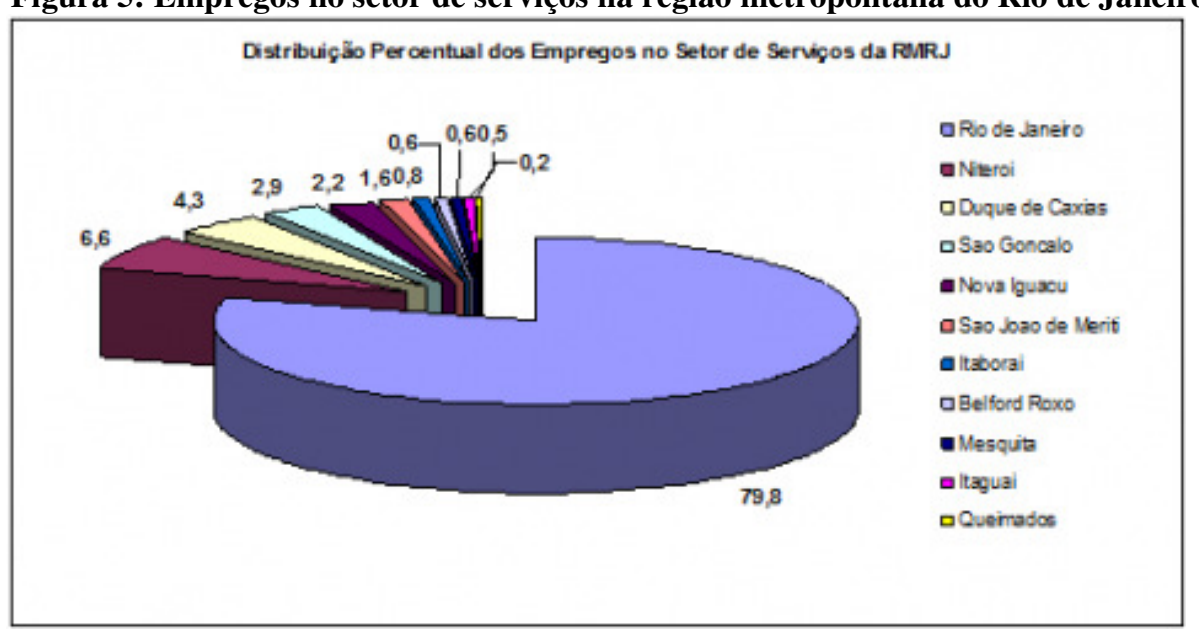

\footnotetext{
${ }^{83}$ RODRIGUES, Juciano Martins. Obra citada.

84 FIRJAN. Mapa de investimentos. Disponível em: http://www.decisaorio.com.br/mapa-deinvestimentos/. Acesso em: 14 de maio de 2016.
} 
Fonte: RAIS/MTE

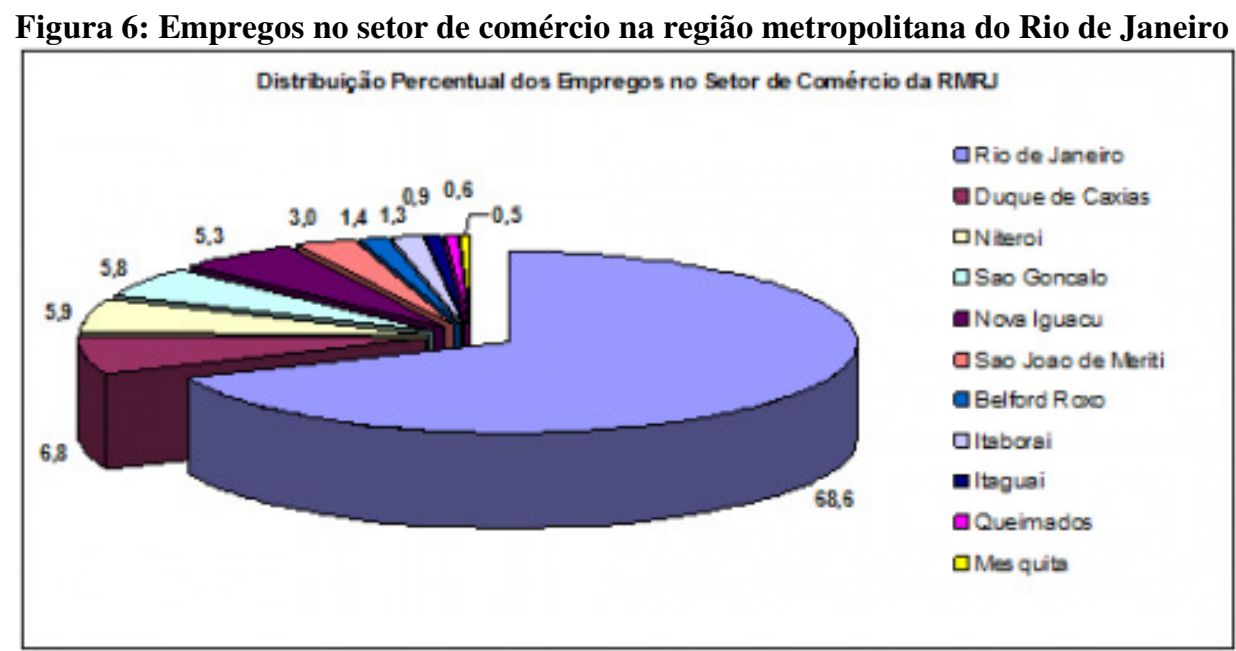

Fonte: RAIS/MTE

Esta alta concentração atrai os habitantes de outros municípios da região metropolitana do Rio de Janeiro para a capital fluminense, pois muitas vezes o mercado de trabalho local não suporta a demanda de pessoas por trabalho. Segundo dados do SEBRAE baseados em um levantamento feito pelo IBGE, 44\% dos habitantes da RMRJ, à exceção da capital, trabalham fora do município de residência, deste total $65,4 \%$ tem como destino a cidade do Rio de Janeiro, o que acarreta um aumento de cerca de $30 \%$ da população da capital entre 6 horas da manhã e às 18 horas, um fluxo de mais de dois milhões de pessoas $^{85}$. Veja a distribuição da população que trabalha no Rio de acordo com os municípios no gráfico seguinte:

\footnotetext{
${ }^{85}$ SEBRAE. Mobilidade urbana e mercado de trabalho na Região Metropolitana do Rio de Janeiro. Disponível

em: https://www.google.com.br/url?sa=t\&rct=j\&q=\&esrc=s\&source=web\&cd=1\&cad=rja\&uact $=8 \& v e d=0$ ahUKEwiJ1M2m79zMAhXGDpAKHYjsDBcQFggfMAA\&url=http\%3A\%2F\%2Fwww.iets.org.br\%2 Fdownload-documentonoticia\%2Fapresentacao_estudo_mobilidade_pptx_1378428282_1378496769.pdf\&usg=AFQjCNH8g 3fb-Aat6VduVrOoTxtU3J2Slg\&bvm=bv.122129774,d.Y2I. Acesso em: 14 de maio de 2016.
} 
Figura 7: pessoas que trabalham na cidade do Rio de Janeiro

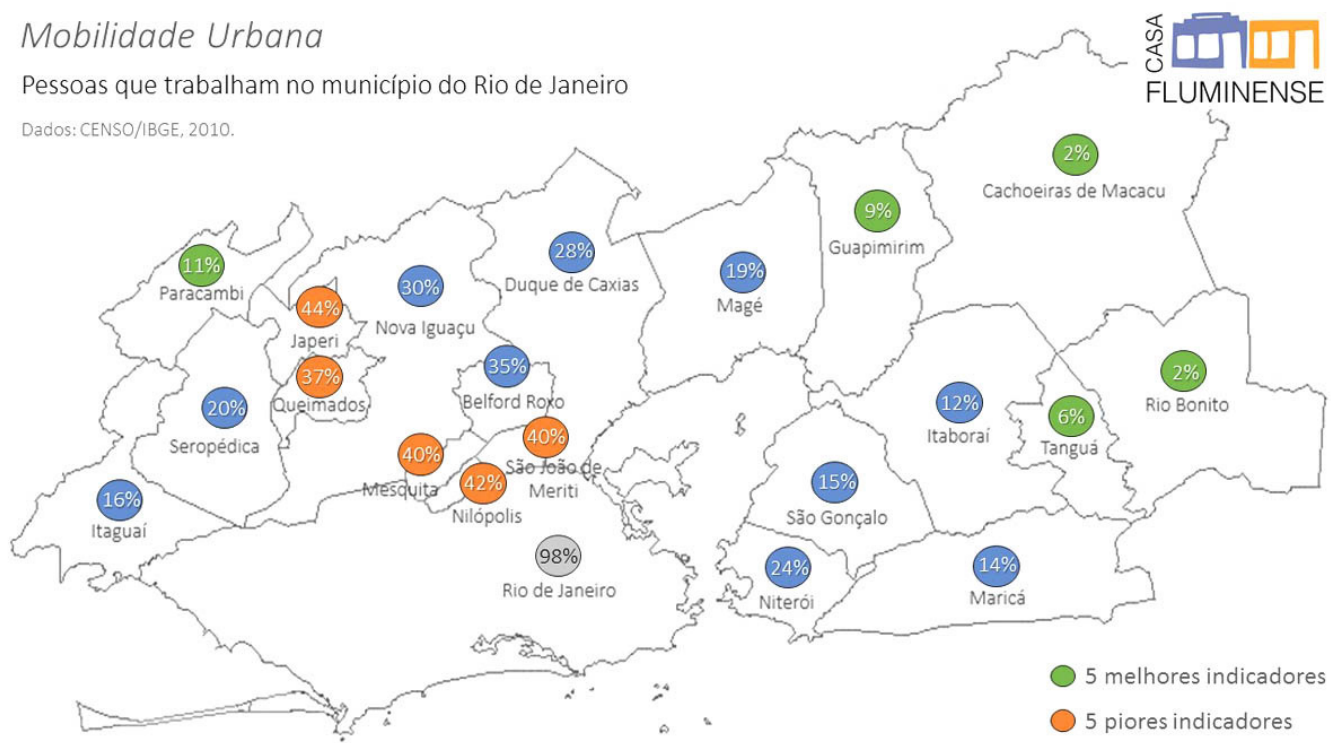

Fonte: Fórum Rio

E o percurso não é fácil! O equivalente a $61 \%$ dos habitantes da região metropolitana gasta mais de uma hora no deslocamento casa-trabalho por dia. Os municípios de Japeri, Queimados, Nova Iguaçu, Magé e Belford Roxo lideram o ranking de tempo gasto no trânsito ${ }^{86}$ e são justamente as áreas que possuem um dos maiores percentuais de pessoas que trabalham na cidade do Rio de Janeiro.

Entre aqueles que trabalham ou estudam do município do Rio, $80 \%$ utilizam os ônibus intermunicipais ${ }^{87}$ para chegar até a capital. Ocorre que das 149 linhas intermunicipais que ligam as cidades da RMRJ ao centro do Rio e adjacências todas tem seu itinerário passando pela Avenida Brasil ${ }^{88}$.

\footnotetext{
86 Trânsito caótico 'rouba' 22 dias por ano dos trabalhadores do Grande Rio. Disponível em: http://s0.ejesa.ig.com.br/infograficos/15/09/11-deslocamento.jpg. Acesso em: 14 de maio de 2016.

87 Governo do Estado do Rio de Janeiro. Secretaria de Transporte. Disponível em: http://www.rj.gov.br/web/setrans/exibeconteudo?article-id=220514. Acesso em: 14 de maio de 2016. ${ }^{88}$ Governo do Estado do Rio de Janeiro. Itinerário das linhas intermunicipais. Disponível em:http://www.rio.rj.gov.br/dlstatic/10112/4212875/4125404/ItinerariosLinhasIntermunicipais.pdf. Acesso em: 14 de maio de 2016.
} 
A via possui cerca de $58 \mathrm{Km}$ de extensão, e corta 28 bairros da capital, ligando o bairro de Santa Cruz na Zona Oeste à Zona Portuária, passando pela Zona Norte da cidade. Segundo a Prefeitura do Rio, passam pela avenida um fluxo de 250 mil veículos diariamente ${ }^{89}$. Tal número decorre da localização geográfica da via que possui ligação com as rodovias Rio - São Paulo e Rio Juiz de Fora, as duas principais formas de escoamento de trânsito utilizadas pela população dos municípios da baixada fluminense para chegar ao Centro, Zona Sul e Zona Norte do Rio nos três horários de rush ${ }^{90}$, o que torna a via eminentemente de caráter pendular.

A partir destes dados pode-se concluir que qualquer alteração na Avenida Brasil afetará em muito os habitantes da região metropolitana, principalmente os que moram fora do município do Rio de Janeiro. A implantação de um corredor BRT que suprime as faixas exclusivas de ônibus ${ }^{91}$ (amplamente utilizada pelos ônibus intermunicipais) e a construção de terminais BRT justamente nos pontos de intersecção da avenida com as rodovias Rio-São Paulo e Rio-Juiz de Fora, sem dúvida impactará a população da região metropolitana que depende deste meio de transporte.

A própria gestão municipal divulga o BRT TransBrasil como uma importante ligação com as cidades da baixada fluminense ${ }^{92}$. Segundo a Prefeitura, o novo transporte atenderá 900 mil pessoas por dia e a maior demanda ocorrerá nos horários de pico, ou seja, uma das tarefas do TransBrasil será ocupar o papel dos ônibus intermunicipais que passam na via.

\footnotetext{
${ }^{89}$ Prefeitura da Cidade do Rio de janeiro. Disponível em: http://www.armazemdedados.rio.rj.gov.br/. Acesso em 14 de maio de 2016.

90 População enfrenta três horários de pico no trânsito do RJ, diz pesquisa Disponível em: http://g1.globo.com/rio-de-janeiro/noticia/2014/12/populacao-agora-enfrenta-tres-horarios-de-pico-notransito-do-rj.html. Acesso em: 14 de maio de 2016.

91 A faixa seletiva que dará lugar ao corredor BRT, comportava cerca de 600 ônibus por hora e a velocidade dos veículos poderia chegar a $80 \mathrm{Km} / \mathrm{h}$ (REDONDO, Andrea. Aguardando a liberação do tráfego a frente. Disponível em: http://urbecarioca.blogspot.com.br/2015/05/aguardando-liberacao-dotrafego-frente.html\#more. Acesso em: 31 de maio de 2016).

${ }_{92}$ Prefeitura da cidade do Rio de Janeiro. Disponível em: http://www.cidadeolimpica.com.br/transbrasil/. Acesso em: 15 de maio de 2016.
} 
Ocorre que a implantação do projeto, considerado a solução para a mobilidade urbana do Rio de Janeiro, claramente não está preparado para atender toda a população. Em uma apresentação feita pela então secretário de Transporte no Conselho Federal de Engenharia e Agronomia $^{93}$ foi noticiado que a demanda pelo BRT varia de $10 \mathrm{mil}$ a $40 \mathrm{mil}$ pessoas por hora, dependendo da linha. Segundo os dados apresentados seriam 10 mil na Transoeste e Transolímpica, 30 mil na Transcarioca e 40 mil na TransBrasil. Considerando que os ônibus que vão ser usados no corredor podem levar de 160 a 190 ou até 250 passageiros, seriam necessários 160 ônibus para atender a demanda durante uma hora (utilizando os maiores ônibus). O que significa que deve sair um ônibus a cada 22 segundos.

Nitidamente, o sistema não conseguirá atender a todos os passageiros e aqueles que conseguirem utilizar o veículo não terão um sistema seguro e eficiente conforme determina a Constituição Federal. Isto pode ser afirmado analisando os corredores BRTs existentes na cidade, nos quais o intervalo de saída dos ônibus varia de 5 a 10 minutos $^{94}$ e os veículos circulam cada vez mais $\operatorname{lotados}^{95}$. O resultado é que o BRT que está sendo construído já nasce muito aquém da demanda da população.

Ademais, conforme informações divulgadas na audiência pública ${ }^{96}$ que debateu a construção do TransBrasil haverá grandes mudanças nas linhas de ônibus que passam no local. Das linhas municipais: 90 serão transformadas em

\footnotetext{
93 Mobilidade urbana: BRT é apresentado como alternativa para o transporte coletivo no Rio. Disponível em: http://www.confea.org.br/cgi/cgilua.exe/sys/start.htm?infoid=12976\&sid=10. Acesso em:14 de maio de 2016.

${ }_{94}$ Dados extraídos do site http://www.brtrio.com/duvidas.

95 Passageiros sofrem para viajar em ônibus do BRT Transoeste. Disponível em: http:/g1.globo.com/rio-dejaneiro/noticia/2015/03/passageiros-sofrem-para-viajar-em-onibus-do-brt-transoeste.html. Acesso em: 15 de maio de 2016. Referência para BH, BRT já vive lotado em Curitiba e também no Rio Disponível em: http://www.otempo.com.br/cidades/refer\%C3\%AAncia-para-bh-brt-j\%C3\%A1-vive-lotado-em-ctamb\%C3\%A9m-norio-1.782981. Acesso em: 15 de maio de 2015.

${ }^{96}$ Ata de audiência pública. http://doweb.rio.rj.gov.br/visualizar_pdf.php?reload=ok\&edi_id=00002077\&page=76. Acesso em: 15 de maio de 2016.
} 
alimentadoras do sistema BRT, 14 serão extintas, 36 mantidas sem conexão com o corredor expresso e 173 permanecerão com o mesmo itinerário que possuem atualmente. Em relação às linhas intermunicipais: 4 serão mantidas com o itinerário atual, 36 terão conexão com o corredor, e 106 tornam-se alimentadoras. Cabe observar que as linhas intermunicipais que terão seus trajetos inalterados são os ônibus executivos, ou seja, que possuem a tarifa bem acima do padrão e que irão circular em um espaço menor do que o anterior.

Poder-se-ia argumentar que a construção do corredor exclusivo incentivaria a população a buscar outros modais de transporte público, porém olhando para o sistema de mobilidade urbana do Estado do Rio de Janeiro fica claro que atender a sugestão acima não é tão simples, pois o ônibus predomina o transporte público coletivo, como se vê na divisão de modais abaixo:

Figura 8: divisão de modais de transporte na região metropolitana do Rio de Janeiro

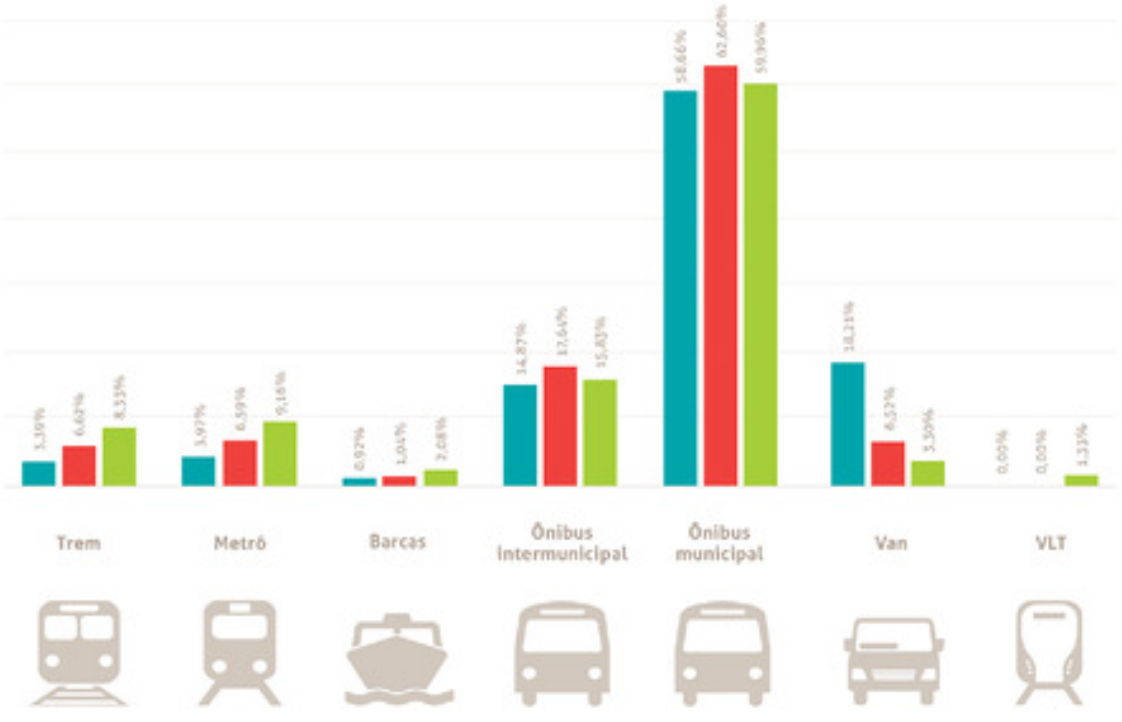

Essa discrepância vem sendo construída e mantida há anos. No início do século passado começaram a circular os primeiros ônibus no Rio de Janeiro, onde antes só circulavam os bondes para curtas distâncias e os ramais de trem 
ligando a Central do Brasil aos municípios da baixada. No governo de Juscelino Kubitscheck o modelo rodoviarista ganhou mais força e os estados e municípios começaram a dar preferência para este modal de transporte. A instalação de fábricas automobilísticas, o lobby dos empresários do ramo somados com a negligência estatal culminou no sistema de transporte que temos hoje, ou seja, predominantemente rodoviário.

$\mathrm{Na}$ região metropolitana do Rio de Janeiro não foi diferente. Enquanto mais estradas eram abertas e novas linhas de ônibus criadas, os ramais de trem permaneceram os mesmos e hoje estão $\operatorname{sucateados}^{97}$, o metrô (um meio de transporte essencialmente metropolitano) surpreendentemente não passa dos limites físicos do município do Rio de Janeiro, as composições andam superlotadas e, após anos de esquecimento, quando são criadas novas linhas todas se dirigem para um único local da cidade: a Barra da Tijuca ${ }^{98}$.

Em suma, a implantação do corredor BRT em uma via que pode ser considerada a mais importante da região metropolitana afetará a população de outros municípios que a compõe, em especial da baixada fluminense, tendo em vista a alta concentração de serviços básicos e equipamentos sociais na cidade do Rio de Janeiro. Aliado a isto, a construção do BRT TransBrasil reforça a divisão modal predominantemente rodoviarista existente na RMRJ e, baseado nos números apresentados pela prefeitura do Rio de Janeiro e nos corredores BRTs em funcionamento atualmente, o transporte não será capaz de atender a demanda.

Sob a perspectiva do direito à cidade, o BRT TransBrasil aparece como um elemento que reforça a segregação social, ele não se propõe o desenvolvimento de outras regiões da metrópole, mas repete a centralidade da

\footnotetext{
97 Quando o Rio de Janeiro terá trens decentes? Disponível em: http://exame.abril.com.br/brasil/noticias/quando-o-rio-de-janeiro-tera-trens-decentes. Acesso em: 15 de maio de 2016.

98 Projeto de novas linhas de metrô no Rio de Janeiro. Disponível em; http://www.metrolinha4.com.br/o-que-e-o-projeto/. Acesso em: 15 de maio de 2016.
} 
cidade do Rio de Janeiro através da valorização de áreas historicamente consolidadas como dominantes, como o Centro e a Zona Sul e abre caminho para a expansão do mercado imobiliário destinado as classes mais altas, tal como a Barra da Tijuca.

A mobilidade urbana não "anda" sozinha. Ela atua como um elemento integrador da cidade, tendo por objetivo contribuir para o acesso universal à cidade (art. $2^{\circ}$ - Lei $\left.\mathrm{n}^{\circ} 12.587 / 2012\right)$ e, portanto, deve estar em sintonia com a política de desenvolvimento urbano e respectivas políticas setoriais de habitação, saneamento, planejamento e gestão do uso do solo, conforme reconheceu o artigo $6^{\circ}$ da lei $n^{\circ} 12.587 / 2012$.

Isto ocorre porque um sistema de transporte tem o poder de induzir a reestruturação do espaço urbano, valorizando certas áreas em detrimento de outras, provocando uma nova concepção das cidades ou repetindo velhos padrões de segregação do território. A obra não atende a necessidade de deslocamento dos habitantes da metrópole, mas ao propósito de concretizar a mesma conduta de seletividade dos investimentos, seja pela perspectiva espacial, seja pelo modelo de transporte escolhido.

A implantação dos corredores BRT por toda a cidade prossegue na lógica de dominação do ônibus no sistema de transporte urbano. Os projetos vieram acompanhados de uma série de políticas de subsídios e desonerações governamentais: i) o ISS do setor de transporte passou de $2 \%$ para $0.01 \%$, cerca de R \$33 milhões deixaram de ser arrecadados; ii) O IPVA sobre a frota foi reduzido em 50\%; iii) a operação de todos os BRTs foi licitada e será administrada através de consórcios de empresas de ônibus; e iv) a concorrência foi diminuída com a extinção de várias linhas municipais e intermunicipais ${ }^{99}$.

\footnotetext{
99 Prefeito sanciona projeto que reduz ISS para ônibus no rio. Disponível em: http://oglobo.globo.com/rio/prefeito-sanciona-projeto-que-reduz-iss-para-onibus-no-rio-2948067. Acesso em: 16 de maio de 2016.
} 
Isto nos permite ter a real dimensão dos impactos do BRT TransBrasil na região metropolitana do Rio de Janeiro e que claramente seus efeitos serão sentidos pela população dos municípios limítrofes, estando enquadrado na definição de função pública de interesse comum prevista pelo art. $2^{\circ}$, II do Estatuto das Metrópoles.

Diante disso, tal obra deveria ser gerida pelo órgão interfederativo da RMRJ com a consulta dos municípios impactados. O projeto do corredor expresso data do ano de 2012/2013 quando ainda não existia a Câmara Metropolitana, mas o Comitê Executivo e o de coordenação dos assuntos metropolitanos já haviam sido criados e poderiam ter sido consultados. Aliás, mesmo após a criação da Câmara Metropolitana no ano passado, a obra, que ainda está em execução e tem previsão de término para 2017, poderia ter sido submetida ao órgão para ajustes.

Entretanto, o que ocorreu foi a gestão isolada de um projeto de interesse metropolitano. A cidade do Rio, em razão de sua importância econômica e social para a região, propôs e executou a obra de forma isolada e agora os outros entes afetados é que deverão se adaptar ao modelo de mobilidade implantado pela gestão municipal do Rio. Neste sentido é a própria fala do prefeito da cidade, Eduardo Paes:

O Rio passa por grandes transformações e cada município tem os seus desafios. E o nosso principal é a mobilidade. Sabemos que a derrubada da Perimetral, por exemplo, impactou diretamente no deslocamento de moradores de outros municípios. Mas também fica inviável melhorar se não houver integração. Como eu revitalizo o Centro do Rio e melhoro a mobilidade se continuar chegando ônibus de sub-bairros da Região Metropolitana? Não dá. E para fazer a Transbrasil, por exemplo, é necessário que os municípios da Região Metropolitana também se integrem ao BRT. ${ }^{100}$

\footnotetext{
${ }^{100}$ Prefeito participa da criação da Câmara Metropolitana de Integração Governamental do Rio de Janeiro. Disponível em: http://www.rio.rj.gov.br/web/guest/exibeconteudo?id=4851270. Acesso em: 16 de maio de 2016.
} 
Reconhece-se a importância da obra em uma escala regional/ metropolitana, mas tais características parecem ter sido convenientemente esquecidas. Os grandes projetos de transporte ficam concentrados no Rio, principalmente na Barra da Tijuca, evidenciando a falta de integração com os municípios metropolitanos, o domínio de interesses do mercado imobiliário e o desprezo pelas reais necessidades de deslocamento da população ${ }^{101}$.

O município do Rio prossegue em uma gestão centralizadora que não reconhece a cidade em escala metropolitana. É a continuidade do modelo dual de cidade centro-periferia, ao qual o resto da região metropolitana terá que se adequar. Prova disso são os projetos apresentados pelo PDTU para implantar BRTs em várias locais da metrópole. Seria um corredor na ponte Rio-Niterói, três corredores em Niterói e São Gonçalo, ligando a BR-101 e terminal de Manilha; terminal Araribóia e terminal Alcântara; e Tribobó e Maricá. Na baixada fluminense um passará na Via Dutra, outro na Via Light, um terceiro ligando o município de Belford Roxo a Duque de Caxias e o quarto vai ligar a baixada até Petrópolis. As obras estão indicadas na imagem abaixo:

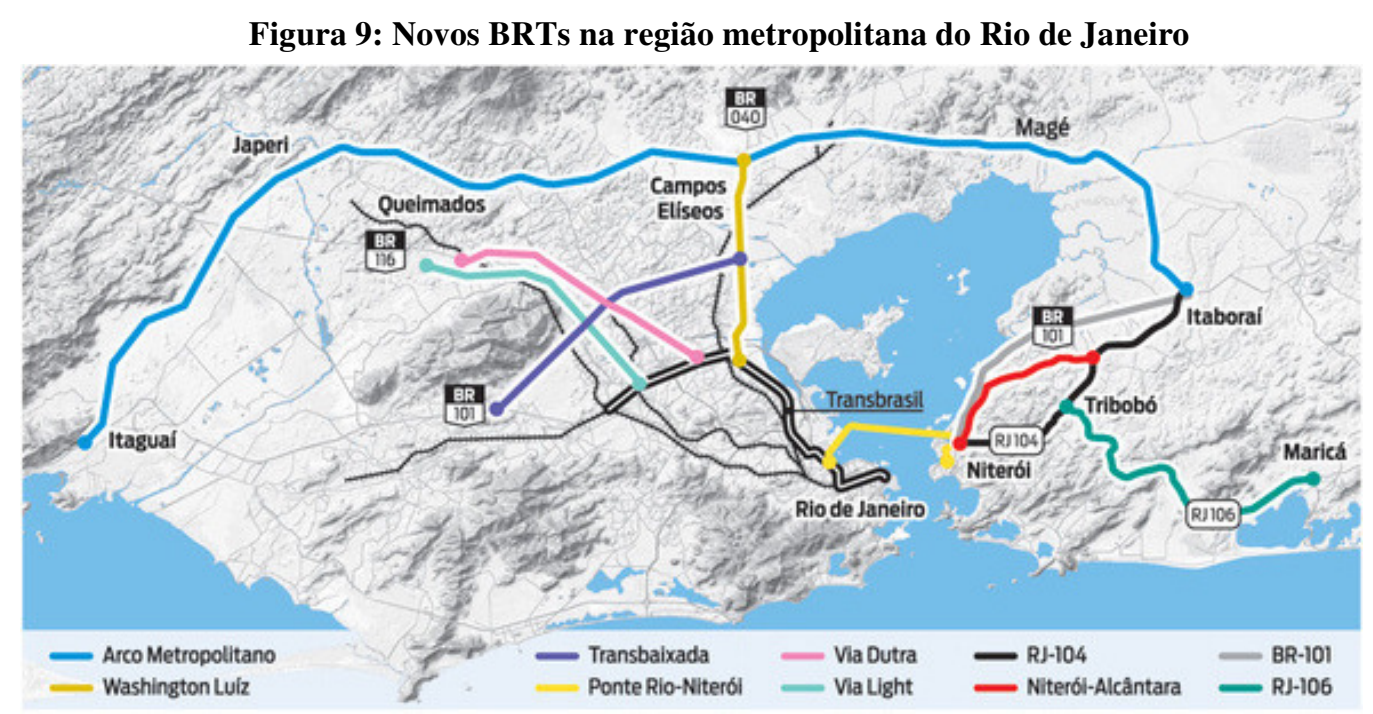

Fonte: PDTU

${ }^{101}$ RODRIGUES, Juciano Martins. O caos do trânsito do Rio de Janeiro tem solução? Disponível em:http://www.observatoriodasmetropoles.net/index.php?option=com_k2\&view=item\&id=760\%3Aocaos-do-tr\%C3\%A2nsito-no-rio-tem-solu\%C3\%A7\%C3\%A3o\%3F\&Itemid=165\&lang=pt. Acesso em: 16 de maio de 2016 
Certo é que a execução da obra discutida neste capítulo tem sido conduzida em total contrariedade com a decisão do STF, e ao espírito do Estatuto das Metrópoles a respeito da gestão metropolitana, pois o interesse de um município se sobrepôs ao de outros que claramente serão impactados pelos atos do primeiro.

Da forma como a construção do BRT TransBrasil está sendo conduzida, o projeto viola a acessibilidade prevista na PNMU, na medida em que inibe a autonomia e dificulta o deslocamento das pessoas. Viola os princípios do desenvolvimento sustentável da cidade, da eficiência, eficácia e efetividade na prestação dos serviços de transporte urbano, bem como o direito do usuário a um serviço adequado ao implantar um modelo de transporte que já nasce superlotado e sem condições de suprir a demanda dos habitantes.

Neste sentido, o projeto não segue as diretrizes da PNMU ao ignorar solenemente a gestão democrática e o controle social do planejamento e avaliação da Política Nacional de Mobilidade Urbana, não consultando toda a população diretamente envolvida que, claramente não pertence somente a cidade do Rio de Janeiro. Violando, por conseguinte, o direito dos usuários de participar do planejamento, da físcalização e da avaliação da política local de mobilidade urbana, conforme dispõe o art. 14, II da Lei n ${ }^{\circ}$ 12.587/2012.

Sobre este último ponto, cabe esclarecer que não se tem notícias da realização de estudo de impacto ambiental e do estudo de impacto de vizinhança do BRT TransBrasil. Inclusive foi feito um requerimento pela ALERJ solicitando a secretaria municipal de urbanismo o envio destes documentos ${ }^{102}$, mas até o momento tal pleito não foi atendido.

\footnotetext{
${ }^{102}$ Requerimento de informações ALERJ. Disponível em: http://mail.camara.rj.gov.br/APL/Legislativos/scpro0711.nsf/bc28bd5455f59815832566ec0018d83f/64 83531077b81bf503257a4e00644505?OpenDocument. Acesso em: 16 de maio de 2016.
} 
O que se sabe é que as iniciativas da prefeitura para solucionar os congestionamentos da avenida Brasil foram inspiradas no Transmilênio existente em Bogotá, que é conhecido como o maior BRT em funcionamento no mundo e que será superado pelo BRT Transbrasil, porém o corredor colombiano já mostra sinais de desgaste com o excesso de passageiros, poluição ambiental, tarifas altas e congestionamento ${ }^{103}$.

Além disso, os BRTs implantados ao redor do mundo foram colocados em cidades nas quais o transporte coletivo de massa já é bem servido pelo metrô, VLT e outros modais. No caso do Rio de Janeiro, ocorre uma total falta de planejamento e integração, além da predominância do sistema rodoviário como transporte de massa.

É preciso entender que dentro de uma região metropolitana, por mais importantes que sejam os papéis de determinada cidade que a compõe, os municípios não são ilhas isoladas, o primeiro passo para a construção de uma região metropolitana que resguarde os direitos constitucionalmente assegurados é a cooperação dos entes ou, do contrário, veremos a repetição do que vem ocorrendo com a mobilidade urbana do Rio de Janeiro: a terceira pior cidade do mundo em congestionamento e a que possui o maior tempo de deslocamento entre as metrópoles do país.

103 CESAR, Yuriê. Em Bogotá, Transmilênio dá sinais de esgotamento. Disponível em: http://www.mobilize.org.br/noticias/7722/em-bogota-brt-transmilenio-da-sinais-de-esgotamento.html. Acesso em: 31 de maio de 2016. 


\section{Conclusão}

A atual Constituição Federal de 1988, trouxe no $\S 3^{\circ}$ de seu artigo 25 , uma nova dimensão para a instituição das regiões metropolitanas, aglomeração urbanas e microrregiões, passando aos estados a atribuição que antes era da União de instituir as regiões metropolitanas, a fim de facilitar a execução das funções públicas de interesse comum.

O texto constitucional também alterou a dinâmica do federalismo brasileiro, com a inclusão do município como ente federativo e o reconhecimento da autonomia conquistada ao longo das Constituições anteriores, sendo lhe atribuída a competência para executar as atribuições afetas ao interesse local.

Conciliar estas duas alterações quando a Constituição se mostra silente quanto ao assunto, transformou-se em uma tarefa da doutrina e da jurisprudência, principalmente quando falamos sobre as funções públicas de interesse comum entendidas como "política pública ou ação nela inserida cuja realização por parte de um Município, isoladamente, seja inviável ou cause impacto em Municípios limítrofes" (art.2º II - lei nº 13.089/2015).

De acordo com a decisão do Supremo Tribunal Federal na ADI $n^{\circ}$ 1.842/RJ, as deliberações sobre estas funções devem ser feitas de forma que seja assegurada a participação de todos os entes envolvidos, não necessariamente igualitária, mas sem que um ente decida isoladamente sobre a execução das FPCIs.

Posteriormente tivemos a promulgação do Estatuto das metrópoles que dispôs sobre a necessidade de estabelecer uma estrutura de governança interfederativa para as metrópoles, bem como um plano de desenvolvimento integrado para orientar as ações que são executadas no território metropolitano.

Paralelamente, também foi criada a política nacional de mobilidade urbana. Tardia em comparação com os problemas enfrentados pela população, 
a lei $12.587 / 2012$ visa reverter o atual sistema de mobilidade existente nas cidades brasileiras (no qual modal rodoviário predomina) com 0 reconhecimento dos meios não motorizados de transporte e a priorização efetiva dos modos coletivos, a observância do direito à cidades sustentáveis, do direito à mobilidade, da gestão democrática.

Além disso, a legislação também determinou a criação dos planos municipais de mobilidade urbana devidamente integrados aos respectivos planos diretores, colocando o município como principal ator no desenvolvimento da mobilidade urbana.

Contudo, a despeito da Constituição Federal de 88 ter atribuído ao ente municipal a competência para planejar e executar o transporte local, dentro de uma região metropolitana esta atribuição deve ser analisada com cuidado. Isto porque, obras que em um primeiro momento seriam de interesse local, podem impactar todo o território metropolitano, tornando-se uma função pública de interesse comum, razão pela qual sua elaboração passará a ser de interesse regional.

Considerando estes conceitos e implicações a obra do BRT TransBrasil foi analisada, dando especial atenção aos impactos metropolitanos enfrentados pela população da RMRJ.

De acordo como os dados expostos a distribuição espacial de melhor infraestrutura urbana com grandes ofertas de trabalho, educação e lazer estão concentradas em apenas uma parte da região metropolitana do Rio de Janeiro. Em contrapartida a dinâmica de residência dos trabalhadores da RMRJ não segue necessariamente essa regra. Embora a cidade do Rio de Janeiro seja a área que agrupe grande parte dos postos de trabalho, existe uma grande quantidade de habitantes que moram em outras locais da região.

Para esta parcela da população, as questões à mobilidade urbana e acessibilidade possuem um aspecto significativo, não apenas como garantia de 
inserção na atividade econômica, mas também como concretização do direito à cidade.

O papel da mobilidade, enquanto indutor de crescimento das infraestruturas urbanas e integração da cidade, já foi reconhecido pela legislação vigente, mas só se concretiza quando acompanhado de um efetivo planejamento urbano que vise o aprimoramento e a igualdade de condições de desenvolvimento econômico e social de toda a região metropolitana.

Tal objetivo não pode ser concretizado fora de uma esfera interfederativa com a participação efetiva dos entes envolvidos e da população diretamente afetada, observando as diretrizes da gestão democrática e a construção de cidades sustentáveis previstas na Constituição Federal, nos estatutos da cidade, da metrópole e na política nacional de mobilidade urbana.

A realização da Copa do Mundo de futebol de 2014 e as Olimpíadas de 2016 tornaram-se o ponto principal do discurso do município do Rio de Janeiro para a reformulação dos sistemas de transporte da cidade, tem evidenciado a prevalência da "vocação turística" sobre a condição de município metropolitano, repetindo a mesma lógica de distribuição de recursos, revalorizando as velhas centralidades e criando novas como a Barra da Tijuca.

Neste contexto, em que as reivindicações do mercado imobiliário são mais atendidas do que as reais necessidades de deslocamento da população metropolitana, a obra do corredor BRT TransBrasil aparece como um meio de transporte de impactos metropolitanos que está sendo tratado como interesse local. Uma obra que rasga a cidade de ponta a ponta, afeta inúmeras pessoas e altera a dinâmica do sistema de transporte intrametropolitano não pode ser executada como um projeto de interesse local.

O projeto se mostra como uma clara violação ao direito à mobilidade, a cidade e ao planejamento da mobilidade urbana. Isso é causado principalmente pela falta de uma estrutura decisória interfederativa que permite a continuidade 
de velhos modelos de valorização de certas localidades em detrimento de outras, acentuando a desigualdade entre os municípios da região metropolitana e o agravamento dos problemas de mobilidade enfrentados pelos habitantes da RMRJ.

Enquanto questões metropolitanas forem enfrentadas como interesses meramente locais não vislumbraremos mudanças no cenário de caos atual. 


\section{Referências}

ALVES, Alaôr Caffé. Regiões Metropolitanas, Aglomerações Urbanas e Microrregiões: Novas Dimensões Constitucionais da Organização do Estado Brasileiro. Pg..05. Disponível em: < http://www.pge.sp.gov.br/centrodeestudos/revistaspge/revista/tes1.htm >. Acesso em: 6 de outubro de 2015.

BRASIL. Lei $\mathrm{n}^{\mathrm{o}} 13.089$, de 12 de janeiro de 2015. Institui o Estatuto da Metrópole, altera a Lei no 10.257 , de 10 de julho de 2001, e dá outras providências. Disponível em: <http://www.planalto.gov.br>. Acesso em: 28 de outubro de 2015.

Constituição Imperial, de 25 de março de 1824. Disponível em: $<$ http://www.planalto.gov.br>. Acesso em: 22 de outubro de 2015.

. Constituição de 1891, de 24 de fevereiro de 1891. Disponível em: <http://www.planalto.gov.br>. Acesso em: 22 de outubro de 2015.

Constituição de 1934, de 16 de julho de 1934. Disponível em: <http://www.planalto.gov.br>. Acesso em: 22 de outubro de 2015.

Constituição de 1946, de 18 de setembro de 1946. Disponível em: <http://www.planalto.gov.br>. Acesso em: 22 de outubro de 2015.

Constituição de 1967, de 24 de janeiro de 1967. Disponível em: <http://www.planalto.gov.br>. Acesso em: 22 de outubro de 2015.

Constituição de 1988, de 05 de outubro de 1988. Disponível em: <http://www.planalto.gov.br>. Acesso em: 22 de outubro de 2015.

Lei $\mathrm{n}^{\circ}$ 12.587, de 03 de janeiro de 2012. Institui as diretrizes da

Política Nacional de Mobilidade Urbana; revoga dispositivos dos DecretosLeis nos 3.326, de 3 de junho de 1941, e 5.405, de 13 de abril de 1943, da Consolidação das Leis do Trabalho (CLT), aprovada pelo Decreto-Lei no 
5.452, de 1o de maio de 1943, e das Leis nos 5.917, de 10 de setembro de 1973, e 6.261, de 14 de novembro de 1975; e dá outras providências. Disponível em: < http://www.planalto.gov.br/ccivil_03/_ato20112014/2012/lei/112587.htm>. Acesso em: 13 de abr de 1016.

Lei $\mathrm{n}^{\mathrm{o}} 10.257$, de 10 de julho de 2001 . Regulamenta os arts. $182 \mathrm{e}$ 183 da Constituição Federal, estabelece diretrizes gerais da política urbana e dá outras providências. Disponível em: < http://www.planalto.gov.br/ccivil_03/leis/LEIS_2001/L10257.htm>. Acesso em: 10 de abr. 2016.

BARROSO, Luís Roberto. Saneamento básico: competências constitucionais da União, Estados e município. Revista Eletrônica de Direito administrativo econômico (REDAE). Pg.17. Salvador, Instituo Brasileiro de Direito público, no11, agosto/setembro/outubro, 2007. Disponível em: http://www.direitodoestado.com.br/redae.asp. Acesso em: 19 de outubro de 2015.

Dicionário online de português. Disponível em: <http://www.dicio.com.br/comum/>. Acesso em: 10 de out. 2015.

CAVALLAZZI, Rosângela Lunardelli. Apud FITTIPALDI, Mariana. Direito à Cidade: diálogo de equidade entre o direito à moradia e o direito ao meioambiente. Disponível em: https://www.google.com.br/url?sa=t\&rct=j\&q=\&esrc=s\&source=web\&cd=2\& cad=rja\&uact=8\&ved=0ahUKEwiJweHowOnMAhXJhZAKHSKuDjcQFggfM AE\&url=http\%3A\%2F\%2Fwww.dominiopublico.gov.br\%2Fdownload\%2Ftes te\%2Farqs\%2Fcp077268.pdf\&usg=AFQjCNHkG5IL7olBcJ59YeEGHJgagaCQ. Acesso em: 06 de maio de 2016. 
CEPERJ.

Disponível

em:

http://www.ceperj.rj.gov.br/ceep/info_territorios/divis_regional.html.Acesso em: 13 de maio de 2016.

CUNHA, Débora Ferreira da. MELO, Elcileni de Melo Borges Lucelena. A Integração da Rede de Transporte Coletivo da Região Metropolitana de Goiânia in: Funções Públicas de Interesse Comum nas Metrópoles Brasileiras: transportes, saneamento básico e uso do solo. p.244

FERNANDES, Edésio. Gestão metropolitana. Caderno Escola Legislativo, Belo Horizonte, v.7, n. 12, p. 70, jan. /jun.2004.

FERREIRA FILHO, Manoel Gonçalves. Curso de direito constitucional. 25. ed. São Paulo: Saraiva, 1999.

FIRJAN. O custo da (i)mobilidade nas regiões metropolitanas do Rio de $\begin{array}{lllll}\text { Janeiro } & e & \text { São } & \text { Paulo } & \text { Disponível }\end{array}$ http://www.firjan.com.br/publicacoes/publicacoes-de-economia/os-custos-da-imobilidade-nas-regioes-metropolitanas-do-rio-de-janeiro-epaulo.htm>. Acesso em: 13 de abr de 2016;

FIRKOWSKI, Olga. MOURA, Rosa. Estatuto da Metrópole: contribuição ao debate.

Disponívelem: $<$ http://web.observatoriodasmetropoles.net/index.phpoption=co m_content\&view=article \&id=454\%3Aestatuto-da metropolecontribuicaoaodebate $\&$ catid $=34 \% 3$ Aartigos $\&$ Itemid=124\&lang=pt $>$. Acesso em: 20 mar 2016.

GOUVEIA, Ronaldo Guimarães. A questão metropolitana no Brasil. p.91. Disponível em: https://www.google.com.br/url?sa=t\&rct=j\&q=\&esrc=s\&source=web\&cd=4\& cad=rja\&uact=8\&ved=0ahUKEwjQh8L5snMAhVIgZAKHTxjArEQFggsMA M\&url=http\%3A\%2F\%2Fbooks.google.com.br\%2Fbooks\%2Fabout\%2FA_qu est\%25C3\%25A3o_metropolitana_no_Brasil.html\%3Fid\%3Df4jp09317uIC\&u 
sg=AFQjCNFeg1yQettsDIU_TgEXhqRA\&bvm=bv.122448493,d.Y2I. Acesso em: 09 de maio de 2016.

GRAU, Roberto. Regiões Metropolitanas: regime jurídico. São Paulo: José Bushatsky, 1974.

GUTIERREZ, Andrea. Direito à mobilidade. Disponível em: http://cidadeemmovimento.org/direito-mobilidade-direitos-e-mobilidade. Acesso em:10 de maio de 2016.

HOTZ. Eduardo Fontes. A Organização metropolitana pós Constituição de 1988. São Paulo em perspectiva. São Paulo, 2014. p.93.

IBGE, Diretoria de Pesquisas, Coordenação de População e Indicadores Sociais, Pesquisa de Informações Básicas Municipais 2015. Disponível em:< http://www.ibge.gov.br/home/estatistica/economia/perfilmunic>. Acesso em: 14 de abr de 2016.

INSTITUTO DE PESQUISA ECONÔMICA APLICADA - IPEA. Comunicado 128 - A nova Lei de Diretrizes da Política Nacional de Mobilidade Urbana. Disponível em: http://www.ipea.gov.br/portal/images/stories/PDFs/comunicado/120106_comu nicadoipea128.pdf. Acesso em: 13 de abr de 2016.

INSTITUTO NACIONAL DE CIÊNCIA E TECNOLOGIA. Índice de Bemestar Urbano. Disponível em:< https://www.google.com.br/url?sa=t\&rct=j\&q=\&esrc=s\&source=web\&cd=1\& $\mathrm{cad}=\mathrm{rja} \&$ uact=8\&ved=0ahUKEwjm_a63sunMAhVFGZAKHYSJAcQQFggc MAA\&url=http $\% 3 \mathrm{~A} \% 2 \mathrm{~F} \% 2 \mathrm{Fwww}$. observatoriodasmetropoles.net $\% 2 \mathrm{Fdownlo}$ ad\%2Findice_bem_estar_urbano.pdf\&usg=AFQjCNHtw9nadrxOKVsP9rH3D L0aC09Lhw> Acesso em: 20 de maio de 2015) 
MARICATO, Ermínia. Metrópoles desgovernadas. Estudos Avançados, v.25, n.71, pp.7-22. 2011.

MORAES, Alexandre. Competência: trânsito e transporte intermunicipal. p.37. Disponível em: <http://www.revistajustitia.com.br/revistas/3dy1dz.pdf>. Acesso em:04 de abr.2016.

MOREIRA NETO, Diogo de Figueiredo. Poder concedente para o abastecimento de agua. Revista de direito administrativo, Rio de janeiro:2013 jul/set 1998.

NOVAES, Patrícia Ramos. Política urbana e gestão democrática: 10 anos de Estatuto da Cidade. Disponível em: http://www.observatoriodasmetropoles.net/index.php?option=com_k2\&view=i tem\&id=499\%3Apol\%C3\%ADticagest\%C3\%A3democr\%C3\%A1tica-10anos-de-estatuto-da-cidade \&Itemid=165\&lang=pt. Acesso em: 06 de maio de 2016.

Observatório das Metrópoles. Unidades Territoriais Urbanas no Brasil: Regiões Metropolitanas, Regiões Integradas de Desenvolvimento Econômico e Aglomerações Urbanas em 2015. Disponível em:http://www.observatoriodasmetropoles.net/index.php?option=com_k2\&vie $\mathrm{w}=\mathrm{item} \& \mathrm{id}=1157 \% 3$ Arelat $\% \mathrm{C} 3 \% \mathrm{~B} 3$ rio-unidades-territoriais-urbanas-nobrasil\&Itemid=169. Acesso em: 06 de maio de 2016.

RIO DE JANEIRO. Constituição do Estado do Rio de Janeiro, de 05 de $\begin{array}{llll}\text { outubro de } & 1989 . & \text { Disponível }\end{array}$ $<\mathrm{https}$ //Www.google.com.br/url?sa=t\&rct=j\&q=\&esrc=s\&source=web\&cd=2 $\&$ cad=rja\&uact=8\&ved=0ahUKEwixi7S3s6XMAhXFhpAKHRJXD0QQFggi MAE\&url=http\%3A\%2F\%2Falerjln1.alerj.rj.gov.br\%2Fconstest.nsf\%2FPage Co\%3FOpenPage\&usg=AFQjCNHeBhvaD7dCDTZzbBrZnMB0Xk7S7A\&sig 2=yBeDz4Zuq0RO63JK6Po7LA>. Acesso em: 22 de out de 2015. 
RODRIGUES, Juciano Martins. Transformações urbanas e crise da mobilidade urbana no Brasil

hipóteses sobre o caso do Rio de Janeiro no contexto dos megaeventos. Disponível em: http://www.observatoriodasmetropoles.net/index.php?option=com_k2\&view=i tem\&id=736\%3Acrise-de-mobilidade-megaeventos-e-rio-dejaneiro\&Itemid=165\&lang=pt. Acesso em: 06 de maio de 2016.

ROLNIK, Raquel. Plano de transporte? Para quê? Disponível em: < $\mathrm{http} / / /$ observatoriodasmetropoles.net/index.php?option=com_k2\&view=item\&i $\mathrm{d}=616 \% 3$ Aplano-de-transporte\%3F-para-qu\%C3\%AA\%3F-\%7C-raquelrolnik\&Itemid=164\&lang=pt $>$ Acesso em: 23 de abr de 2016.

—. Transporte agora é um direito. Disponível em: https://raquelrolnik.wordpress.com/2015/09/21/transporte-agora-e-um-direito. Acesso em: 23 de abr de 2016.

SILVA, José Afonso da. Apud ASSIS, Carolina Tavares; GRANADO, Emerson de Morais. A função social da propriedade urbana. Revista Eletrônica de Iniciação Científica. Itajaí, Centro de Ciências Sociais e Jurídicas da UNIVALI. v. 4, n.1, p. 382- 393, $1^{\text {o }}$ Trimestre de 2013. Disponível em: www.univali.br/ricc - ISSN 2236-5044.

SOUZA, Celina. "Federalismo, desenho constitucional e instituições federativas no Brasil pós-1988." Revista de Sociologia e Política 24.24 (2005): 105-122.

SOUZA, LEONARDO DA ROCHA DE. Interesse local versus peculiar interesse: análise da atuação dos municípios. RDA - revista de Direito Administrativo, Rio de Janeiro, v. 261, p. 115-145, set./dez. 2012.

STF. ADI n ${ }^{\circ}$ 1.842/RJ, Rel. Ministro Luiz Fux, Brasília, 16 de setembro de 2013. 
TRINDADE, Thiago Aparecido. Direitos e cidadania: reflexões sobre o direito à cidade. In: Lua Nova, São Paulo, 87: 139-165, 2012.

VARGAS, H. C. (2008). Mobilidade Urbana nas Grandes Cidades. São Paulo, $\mathrm{n}^{\circ}$. 47, ano XII, p 7-11, 2008. Disponível em: <http://www.fau.usp.br/depprojeto/labcom/produtos/2008_vargas_imobilidade .pdf>. Acesso em: 15/04/2016.

VASCONCELLOS, E. A. Transporte urbano nos países em desenvolvimento. Reflexões e propostas. São Paulo, Annablume. 2000. Disponível em: <https://books.google.com.br/books/about/Transporte_urbano_nos_p\%C3\%A Dses_em_desenvo.html?id=rkb-RA72qD8C\&hl=pt-BR $>$ Acesso em: 15 de abr de 2016.

VERDAN, Tauã Lima. Breves comentários sobre o Estatuto das metrópoles. Disponívelem:<http://www.boletimjuridico.com.br/doutrina/texto.asp?id=4071 >. Acesso em: 19 de out de 2015. 
